\title{
You Get What You Pay for: Sources and Consequences of the Public Sector Premium in Albania and Sri Lanka
}

Ricardo Hausmann, Ljubica Nedelkoska, and Sehar Noor

CID Faculty Working Paper No. 376

February 2020

(c) Copyright 2020 Hausmann, Ricardo; Nedelkoska, Ljubica; Noor, Sehar; and the President and Fellows of Harvard

College
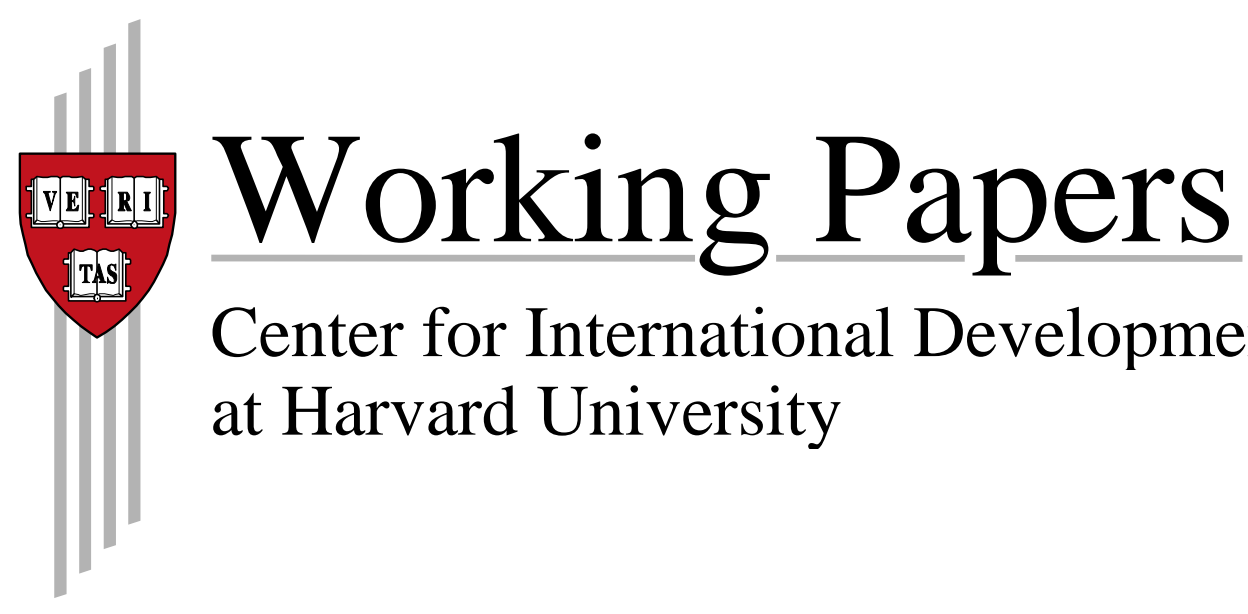

Center for International Development at Harvard University 


\title{
You get what you pay for: Sources and consequences of the public sector premium in Albania and Sri Lanka
}

\author{
Ricardo Hausmann*, Ljubica Nedelkoska† and Sehar Noor $\ddagger$
}

\begin{abstract}
We study the factors behind the public sector premium in Albania and Sri Lanka, the group heterogeneity in the premium, the sources of public sector wage compression, and the impact of this compression on the way individuals self-select between the public and the private sector. Similar to other countries, the public sectors in Albania and Sri Lanka pay higher wages than the private sector, for all but the most valued employees. While half of the premium of Sri Lanka and two-thirds of it in Albania are explained by differences in the occupation-educationexperience mix between the sectors, and the level of private sector informality, the unexplained part of the premium is significant enough to affect the preferences of working in the public sector for different groups. We show that the compressed distributions of public sector wages and benefits create incentives for positive sorting into the public sector among most employees, and negative sorting among the most productive ones.
\end{abstract}

Keywords: public sector premium, self-selection, Albania, Sri Lanka, wage compression JEL: J31, J32, J38, O57,

* John F. Kennedy School of Government at Harvard University and Santa Fe Institute.

$\dagger$ John F. Kennedy School of Government at Harvard University, corresponding author: Ljubica_nedelkoska@hks.harvard.edu

$¥$ John F. Kennedy School of Government at Harvard University 


\section{Introduction}

This paper studies the factors behind the public sector premium in Albania and Sri Lanka, the group heterogeneity in the premium, the sources of public sector wage compression, and the impact of this compression on the way individuals self-select between the public and the private sector. We show that these two upper-middle income countries that share important similarities but also disparities in the structure and development of their economies, display remarkably similar patterns when it comes to the public-private differences in the pay distribution.

Across the world, and with few exceptions, the public sector pays higher average wages than the private sector for similar employees (Lucifora and Meurs, 2006; Mizala et al., 2011; Gindling et al., 2019). The wage formation in the public sector seems to follow different rules than that in the private sector. Salary increases in the public sector are often irregular and abrupt. They are believed to be less dependent on employee productivity and the forces of labor supply and demand, and more driven by political concerns and union membership. 4 In countries where the public sector does not pay more, public workers have been found to compensate their earnings with bribes (Gorodnichenko and Sabirianova-Peter, 2007).

Governments also seem to, intentionally or as a side-effect of other objectives, use wages and benefits as measures to counteract the economy-wide earnings inequality. Sometimes this is done by increasing the pay in the low and middle part of the pay distribution relative to the top, as was the case in Albania in 2017, and sometimes it is done by directly capping the pay at the top, a case in point being Mexico in 2018 (Whelan and Montes 2018; Hausmann 2018). The resulting wage compression makes the most experienced, best educated, and best paid government employees an exception to the observation of a positive public sector premium: across the world, the top civil servants tend to either have zero or even a negative pay premium (Gregory and Borland, 1999; Panizza et al., 2001; Borjas 2002; Depalo, Giordano and Papapetrou, 2015; Hospido and Moral-Benito, 2016; Lucifora and Meurs, 2006).

The paper is organized as follows. Section 2 provides a contextual background on Albania and Sri Lanka in the period of observation. Section 3 explains the data and the methodology. Section 4 presents the descriptive findings. In Section 5, we analyze how much of the premium is explained by job characteristics and worker endowments, and how much is due to differences in the returns to certain characteristics. Here we also delve into the sources of wage compression, and analyze the group heterogeneity in the premium. Section 6 tests the hypothesis that the

${ }_{4}$ One theory puts forward the idea that, unlike the private sector, which has to internalize the cost of wages, the public sector can afford to pay higher wages by raising taxes (Holmund, 1993; Mueller, 1998). Scholars have also put forth the idea of the public sector premium as a mechanism to buy the political backing of government workers (Courant et al., 1979; Reder, 1975; Borjas, 1980; Borjas, 1984). Public sector workers can moreover form strong interest groups and exert more political pressure through unions and strikes as compared to private sector workers (Gregory and Borland, 1999). 
public sector wage compression affects the way individuals sort themselves into the public and private sector. Section 7 concludes and discusses the policy implications of our findings.

\section{Background on Albania and Sri Lanka}

Albania and Sri Lanka, two upper-middle income countries, have distinct histories and organizations of their public and private sectors, but also many similarities. Among their similarities are prolonged episodes of socialist rule, late transitions to open economies, and currently similar portfolios of economic production. Both of them have relatively small government sectors, amounting to about 15 percent of total employment in the period under observation.

Albania emerged in the early 1990s from a 40-year communist dictatorship and economic autarky. Following a turbulent transition to a market economy in the 1990s, which included a fall of a Ponzi scheme and a civil unrest, the 2000s were a period of high growth, economic diversification, and transition towards governments that resemble those of other South-Eastern European countries. In the period under observation (2012-2016), Albania went through an economic recession (2012-2013), a government change (2013) and a subsequent recovery starting in 2014. The 2013 change in government led to new policies establishing fiscal discipline. This included a freezing of salaries and contributions for a full 4-year term, and limiting the size of the government, which in the observed period contributed between 14 and 18 percent in total employment. In the period under observation, the CAGR of public sector job creation was 1.6 percent. The CAGR of public sector real net wage growth was 3 percent, and this growth was mainly driven by the increasing share of better educated employees in the sector. Within the same time, the private sector was expanding towards services, especially Business Process Outsourcing (BPO) and tourism, while manufacturing was also growing, but at a slower pace. The mining sector, including oil extraction, was undergoing significant fluctuations driven by the change in the international prices of commodities, but these affected a small share of employment because of their high capital intensity. The private sector was also experiencing a rapid formalization following a sequence of government-led anti-informality campaigns starting in 2015. In the private sector (formal and informal), the CAGR of the average real net pay was about zero, while the number of jobs was expanding at a compound annual rate of $6.5 \%$ percent. In 2009, Sri Lanka ended a 26-year civil war, fought between the Liberation Tigers of Tamil Eelam and the Sri Lankan government. Even during the war, Sri Lanka's economy grew at rates similar to those of the rest of East Asia and the Pacific, and this growth was mainly driven by progress made in its largest urban area - the Western Province. As a result, already in the early 2000s Sri Lanka advanced from a low to a middle-income country, and in 2019 it graduated to an upper-middle-income status (World Bank 2019). Throughout the 1960s and the 1970s, Sri Lanka's economic and social policy was shaped by a socialist ideology (The Guardian, 2013). Today's free market economy was introduced in Sri Lanka in 1977. The first three years under observation (2010-2012) in this study were marked by an astonishing growth of over 8 percent 
annually, as large-scale reconstruction efforts for ports, airports, electricity generation, and highways were being realized. After those years, the growth was reduced to 3-5 percent per year. Modest rates of economic growth and high and rapidly growing public debt suggested that the peace dividend was short-lived. In 2015, a new government oriented towards promoting good governance, reconciliation, rule of law and transparency stepped in, but did not succeed in accelerating the rate of growth. In the observed period, the service economy, and in particular tourism and transportation, were expanding fast. The BPO sector was also expanding, although at a slower pace than in Albania. Apparel and footwear were growing, but at a significantly slower rate than the service economy. The CAGR of job creation in the private sector was 2 percent, while that of average real wages was 7.1 percent.

In spite of the government change and more rapid economic growth than in Albania, the public sector as a share of total employment remained at a stable 14-15 percent in the observed period. The job creation in the public sector was also weak, a CAGR of 0.8 percent, while the CAGR of real wages was comparable to that of the private sector, 7.4 percent.

\section{Data and methodology}

\subsection{Data}

We use the Labor Force Surveys (LFS) from two upper middle-income countries, Sri Lanka and Albania. The Sri Lankan LFS (Department of Census and Statistics 2017) is an annual repeated cross-section and we have it available for seven years, from 2010 to 2016. The Albanian Quarterly Labor Force Survey (INSTAT 2017, QLFS) is an individual-level panel, where individuals can be followed for up to five quarters. The QLFS is available for five years, from 2012 to 2016.

\subsection{Sample}

For both labor force surveys, following Katz and Autor (1999) and Borjas (2002), we restrict the sample to full-time workers, defined as individuals who usually work 35 hours or more in a week, and to workers who earned at least half of the minimum wage, (either 10,000 rupees per month or 400 rupees per day in Sri Lanka, and 22,000 lek per month in Albania). These restrictions leave out the categories of employers, self-employed, unpaid family members and those who could not classify their employment because of lack of job stability, from our sample. In Albania, the final sample represents 40 percent of all workers, and the final Sri Lankan sample represents 47 percent of all workers.5 The final Albanian sample has 24,897 observations $(4,9$ million weighted observations) in the period 2012-2016. They represent 9,280 surveyed

5 In Albania, unpaid family workers account for 31 percent of all workers, self-employed for 27 percent, and employers for 2 percent. In Sri Lanka, unpaid family members account for 9 percent of all workers, self-employed for 32 percent, unclassified for another 9 percent and employers for 3 percent. In Sri Lanka, the self-employed and the unclassified also report wages, but we exclude these from the main sample in order to align the samples from the two countries as much as possible. 
individuals. The final Sri Lankan sample has 51,972 observations or 13,2 million weighted observations. The summary statistics for the final samples are reported in Appendix Table A1.

An important difference between the two datasets is that the Sri Lankan wage data reflect gross wages, while Albania's labor force survey data reflect net wages. Moreover, the Sri Lankan wage data include additional earnings such as overtime payments and income in kind translated into rupees, while the Albanian data do not include additional earnings. In both countries, we create variables reflecting hourly wages, which are derived by dividing the calculated weekly wages by the weekly hours worked.6 We deflate these variables using the CPI of each country. The real hourly (gross) wages in Sri Lanka are expressed in 2015 rupees, and the real hourly (net) wages in Albania are expressed in 2012 leks. In the final sample, 44.7 percent of the wageearners work in the public sector in Albania and 32.8 percent work in the public sector in Sri Lanka.

Figure 1. Breakdown of wage earners by sector (private-public), educational level, and gender

a. Albania

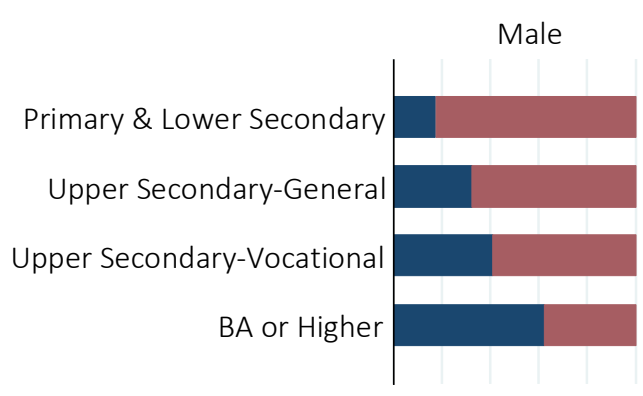

Female

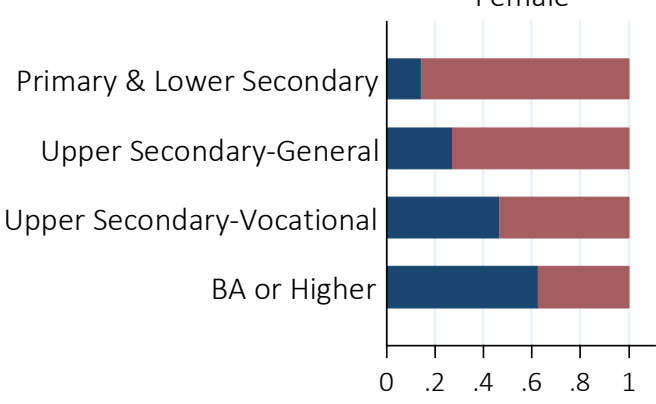

public

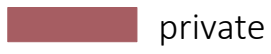

b. Sri Lanka

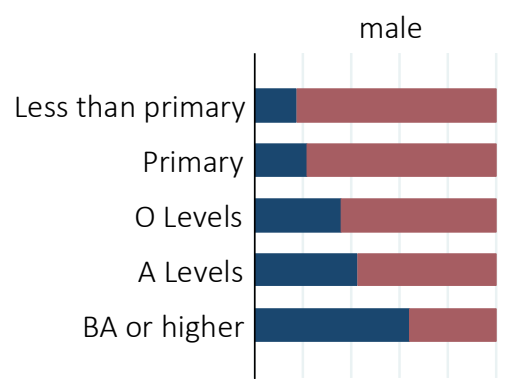

female

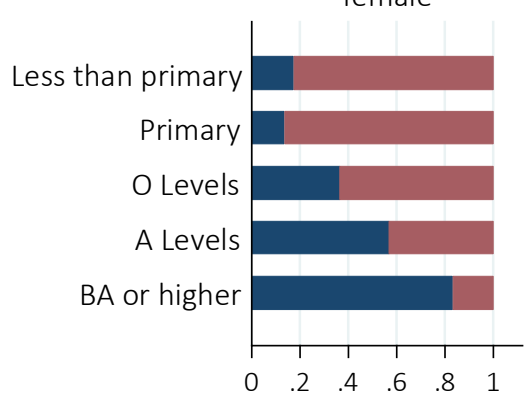

public

private

Figure 1 shows the breakdown of employees in the two sectors by gender and by level of education. In both countries, the share of public sector employees increases with the level of

6 In both countries, a smaller share of workers reports their salaries in daily instead of monthly intervals. In Albania, some also report wages in weekly and bi-weekly intervals. All of these values are translated into weekly earnings and divided by the usual hours worked in a week. 
education. The share of women working in the public sector also increases with the level of education, a pattern that is more pronounced in Sri Lanka than in Albania.

\subsection{Methodology}

We start our analysis by using methods that decompose the sources of group pay difference, as pioneered by Oaxaca (1973) and Blinder (1973). Similar to other studies of the public sector premium (Poterba and Rueben, 1994; Disney and Gosling, 1998; Lucifora and Meurs, 2006; Hospido and Moral-Benito, 2016), we use quantile regression to study how the premium differs by the level of pay. Our analysis of how individuals sort themselves into the public sector based on unobserved characteristics involves the use of individual fixed effects models. Here, the within variance stems from workers that have switched between working in the private and public sector.

\section{Descriptive findings}

We estimate a difference in the net pay in Albania of 34 percent in favor of the public sector. In Sri Lanka, the gross pay difference is 54 percent. 7 In both countries, women have a higher unadjusted public premium than men, and middle-educated employees have the highest unadjusted premium. In both countries as well, the pay inequality is lower in the public sector.

In Albania, women earn 43.3 percent more in the public sector and men earn 29.5 percent more. Among men, a positive pay gap is visible among those with higher than primary education (20 percent), among those with secondary education (12.5 percent) and among those with tertiary education (14 percent). Among women, a positive pay gap is visible at all levels, but the difference is not always statistically significant. A statistically significant premium is present among women with upper secondary general education (27.8 percent), those with upper secondary vocational education (41.9 percent) and those with tertiary education (8 percent, Figure 2a).8

In Sri Lanka, women earn 97.3 percent more in the public sector, and men earn 44 percent more. Unlike in Albania, in Sri Lanka, the earnings of the tertiary educated public sector workers amount to only 84 percent of the earnings of the tertiary educated private sector workers for both men and women. At all other levels, both men and women earn higher wages in the public sector (Figure 2b). Among men, those with less than primary earn on average 24.4 percent more, those with primary earn 36.1 percent more, those with O-levels earn 30.6 percent more, and those with A-levels earn 11.6 percent more. Among women, those with less than primary earn 14 percent

${ }_{7}$ Our most direct comparison of the sectoral pay gap in the two countries can be estimated using monthly gross earnings in the formal sector in 2016. The estimated gap for Sri Lanka is 43.7 percent and for Albania it is 25 percent. The estimate for Sri Lanka is calculated using the LFS 2016 data, and the one for Albania uses the 2016 Albanian administrative tax records, as reported by INSTAT (2019b).

${ }_{8}$ Figure A1 in Appendix A shows the pay ratio between the sectors by country, gender, and level of education over time. 
more, those with primary earn 47.7 percent more, those with O-levels earn 80.3 percent more, and A-level educated women earn 52.6 percent more.

The distribution of wages in the public sector is more compressed in both countries. In Albania, the Gini coefficient is 0.26 in the private sector and 0.19 in the public sector. The corresponding 90/10 inequality ratios are 3.05 and 2.38. In Sri Lanka, the Gini coefficient is 0.33 in the private sector and 0.28 in the public. 9 The corresponding 90/10 inequality ratios are 4.1 and 3.9.

Moreover, in both countries, the pay inequality increases in the private sector with the level of education, and in the public sector it actually decreases with the level of education (Figure 3).

Figure 2. Hourly wages in the public and the private sector by years of education and gender

a. Albania

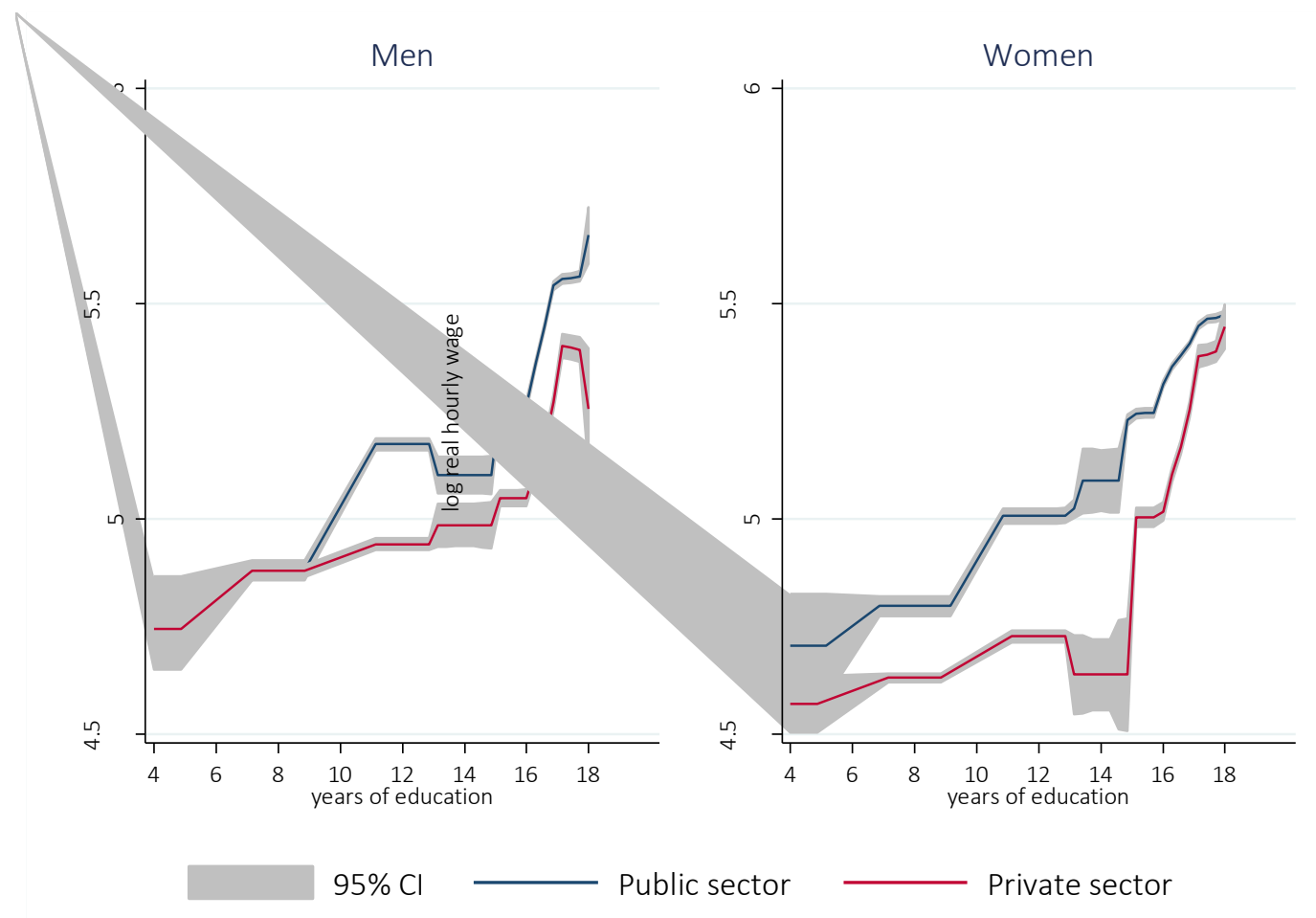

9 The overall income inequality in Albania is comparatively low and in Sri Lanka it is closer to the median country inequality (World Bank, 2019). Income, in addition to wages, includes nonwage sources such as social security payments, pensions, and rental income. 
b. Sri Lanka

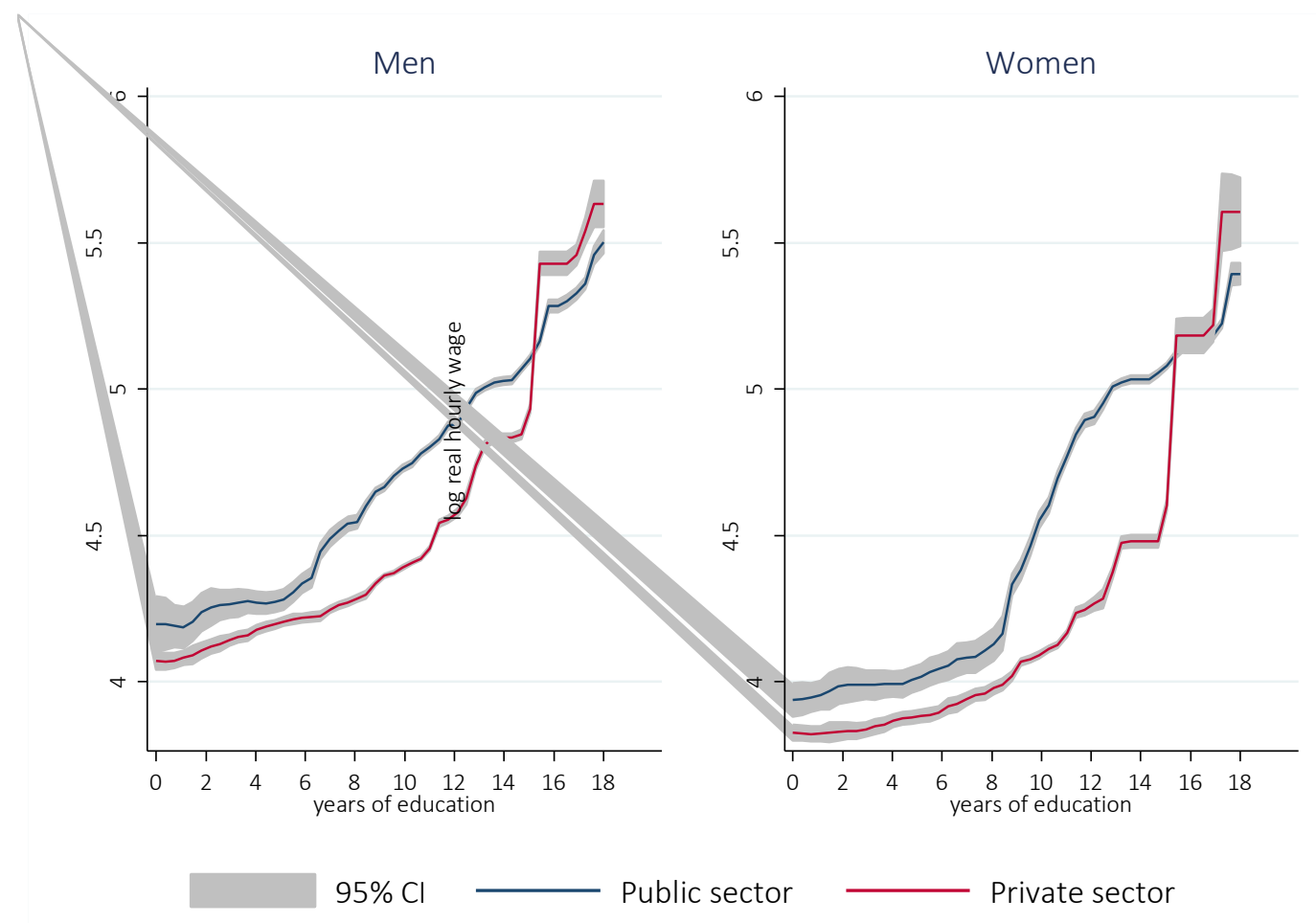

Figure 3. Pay inequality in the public and the private sector by level of education

a. Albania

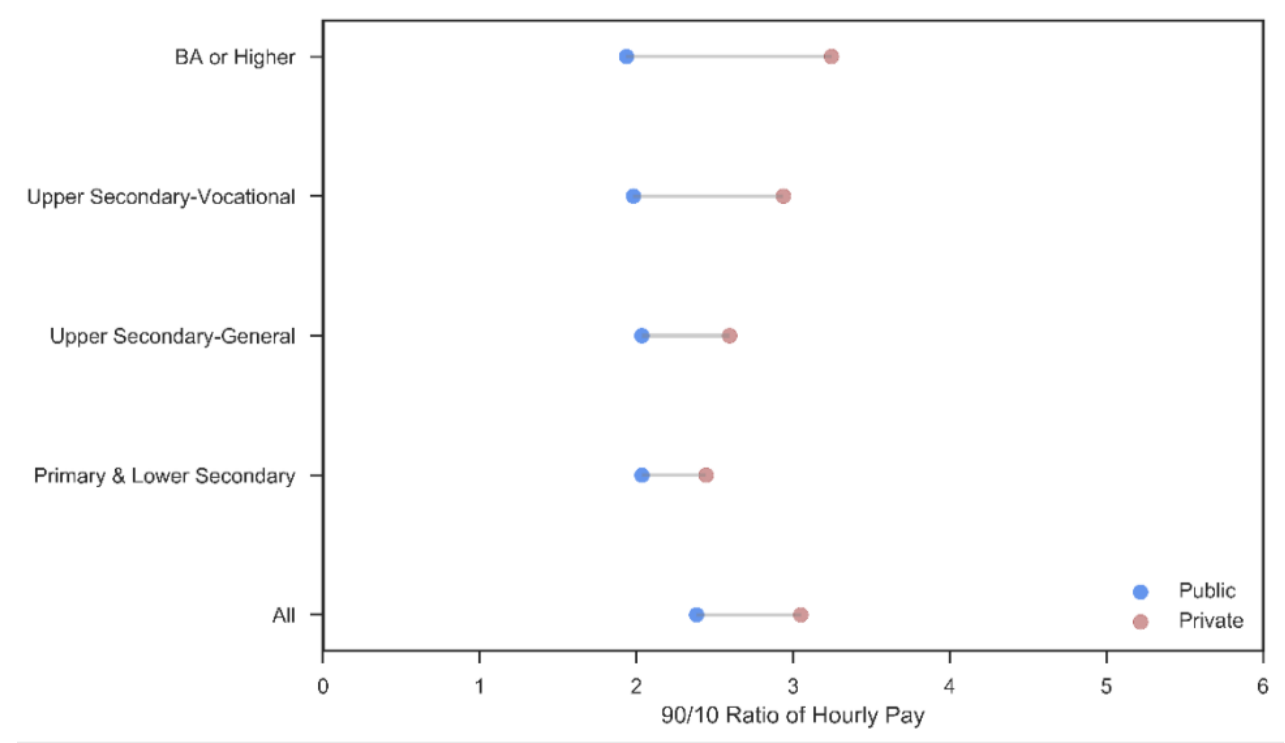


b. Sri Lanka

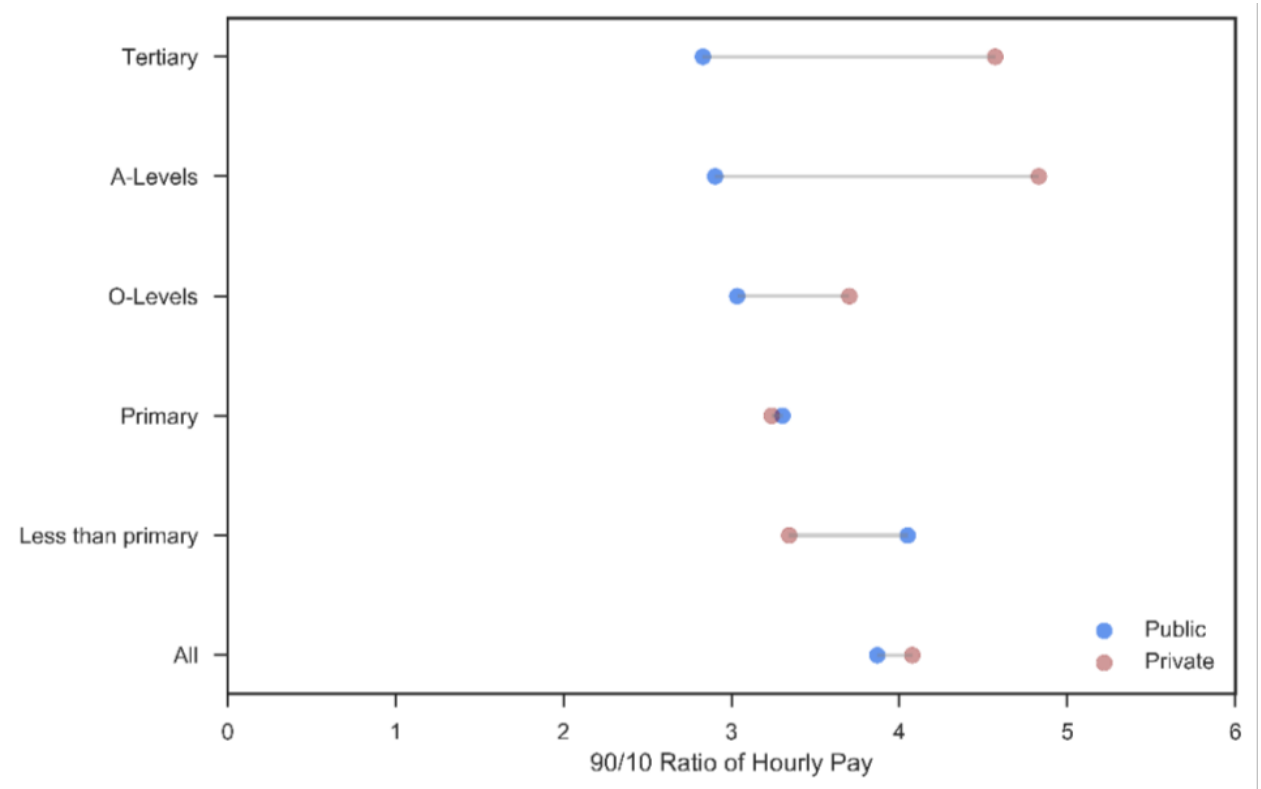

In addition to earning higher wages, in both countries, public sector workers are more likely to have their employers contribute to their pensions, they are more likely to have permanent contracts and are more likely to have paid leave (Figure 4). The overall share of workers receiving benefits is significantly higher in Albania than in Sri Lanka. In Albania, almost all public sector workers ( 99 percent) enjoy employer contributions to pensions, while this is the case with 93 percent of the public sector workers in Sri Lanka. In Albania, 96 percent of all public sector workers have permanent contracts, while this is the case with 90 percent of public sector workers in Sri Lanka. Finally, 96 percent of Albania's public sector workers have right to a paid leave, while 88 percent of Sri Lanka's public sector workers have such benefits.

Figure 4. Share of workers with paid leave, pensions and permanent contracts by sector

a. Albania

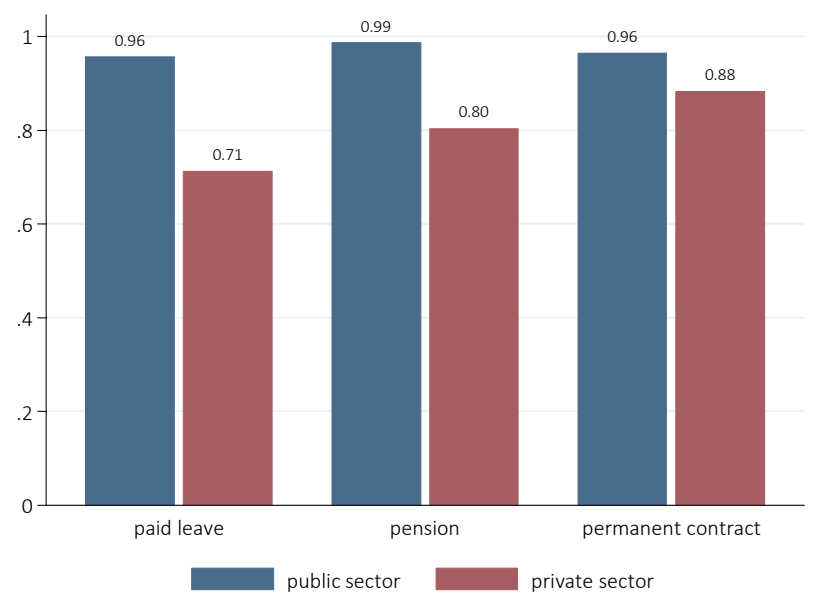

b. Sri Lanka

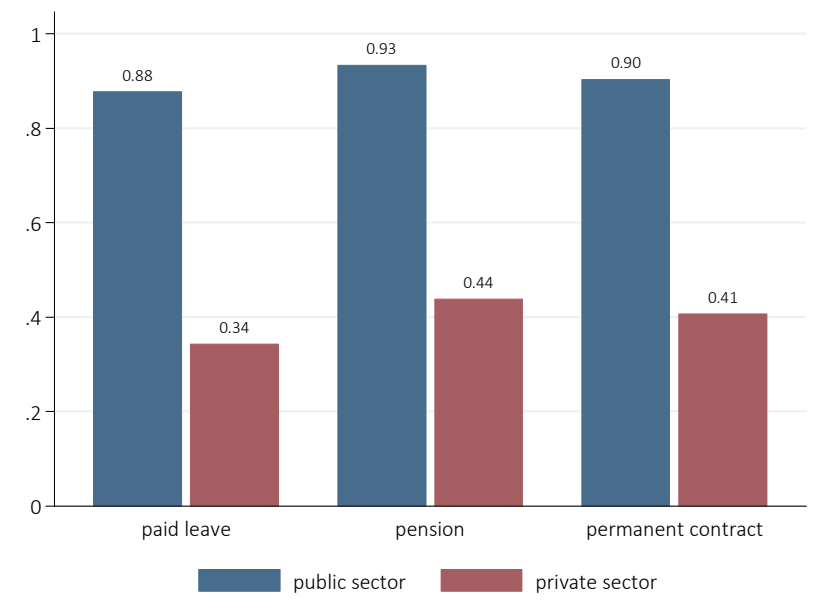


Figure 5. Share of workers receiving benefits by level of education and sector

a. Albania

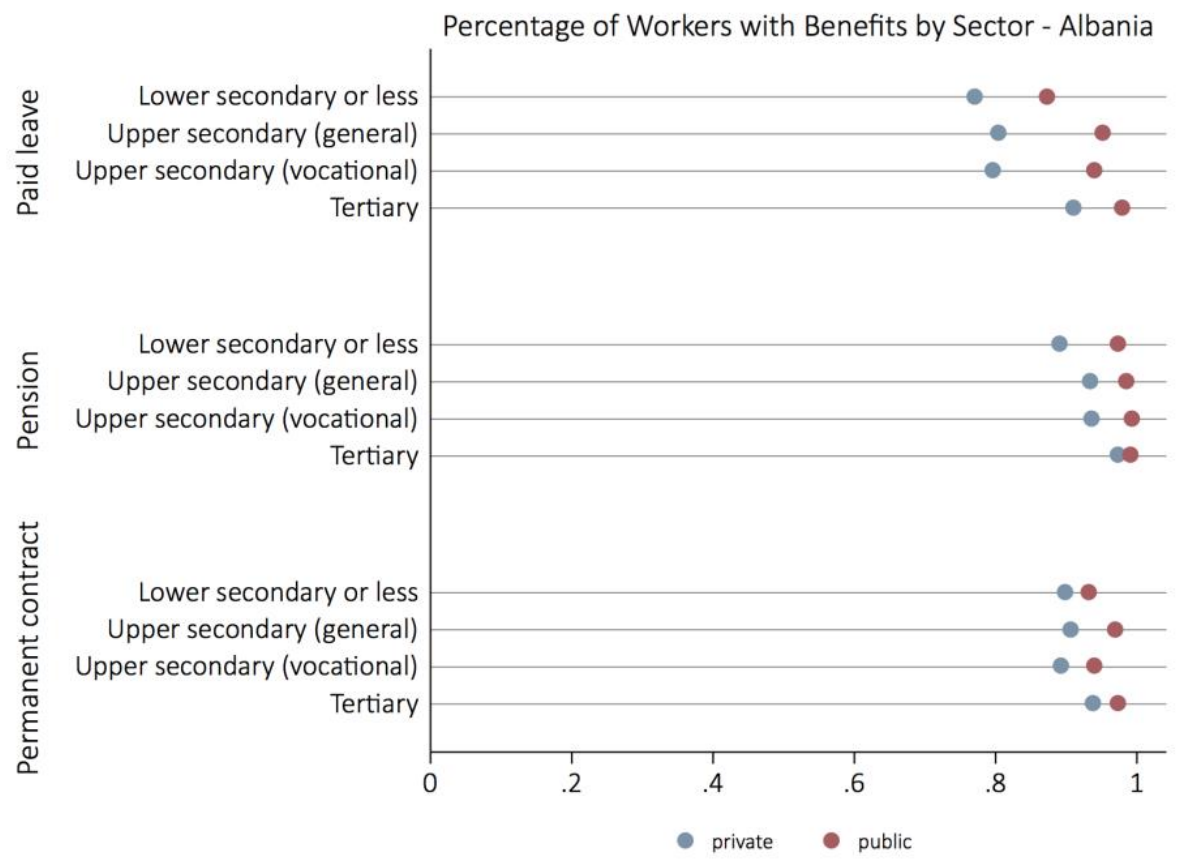

b. Sri Lanka

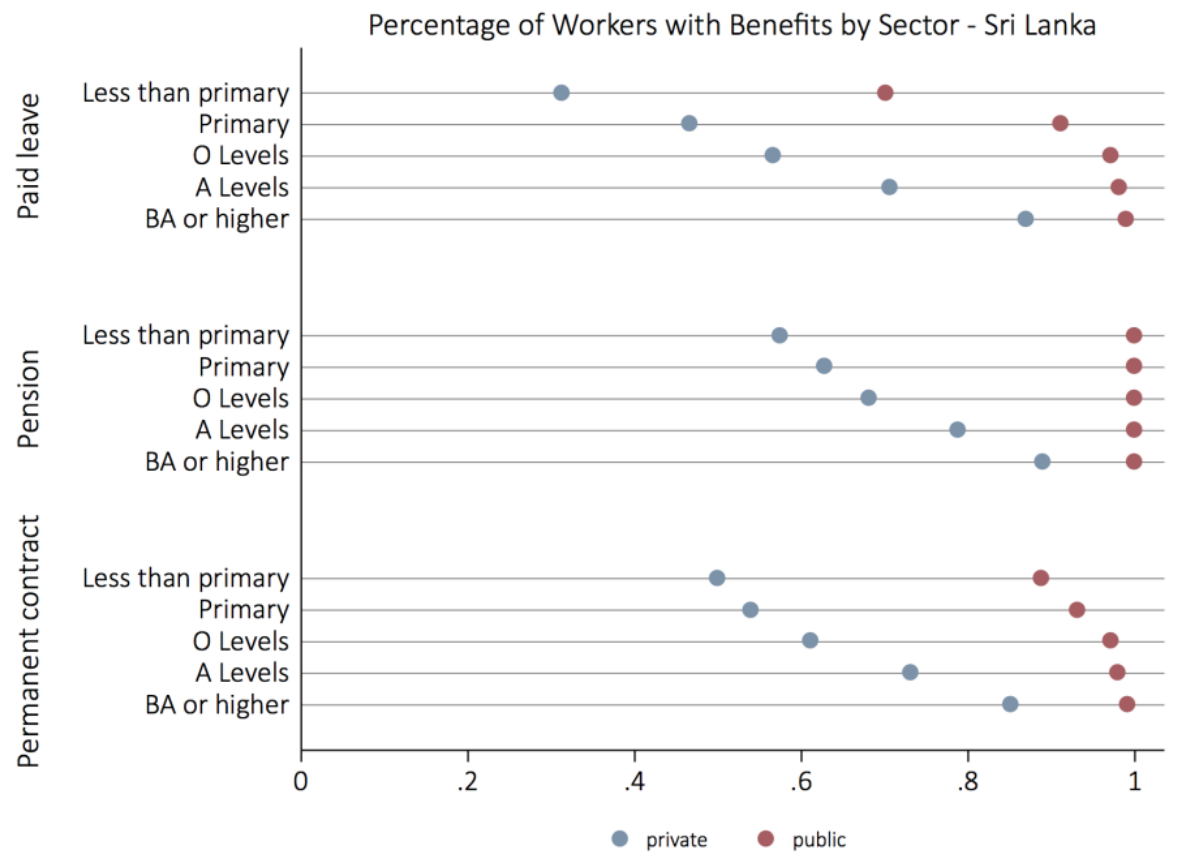

When it comes to the private sector, 80 percent of Albanians in our sample have employersupported pensions, 88 percent have permanent contracts, and 81 percent have a right to paid 
leave. The corresponding shares for Sri Lanka are 44 percent, 41 percent, and 34 percent. On top of these benefits, public sector workers also enjoy significantly shorter working hours in both countries. In both countries, the median public sector worker usually works 40 hours a week, while the median private sector worker usually works 48 hours a week.

The prevalence of benefits depends on the level of education: the more educated workers are more likely to receive benefits, and the sectoral differences in the shares of those receiving benefits decline significantly with the level of education in both countries (Figure 5).10 This pattern is particularly pronounced in Sri Lanka.

\section{Explaining the public sector premium and the public sector pay compression}

The public sector premium may stem from differences in the composition of jobs and employees between the public and private sector, and from differences in the returns to certain worker characteristics such as education and experience. This section studies both potential sources of the public sector premium. We then investigate what causes the observed wage compression in the public sector. Lastly, we study the heterogeneity in the premium by level of pay and by level of educational attainment.

\subsection{Different job and employee composition vs. different returns to employee characteristics}

A feature of any public sector is that its job composition is inherently different from that of the private sector. The public sectors in most countries employ many teachers, healthcare workers and administrators, and the private sectors often employ many blue-collar workers, restaurant workers, engineers and financial analysts, among other professions. A good starting point is therefore to understand how much of the pay differences between the two sectors stem from their systematically different job structures. Using the Oaxaca-Blinder decomposition (Oaxaca, 1973; Blinder, 1973; OB hereafter), we break down the wage gap into two components: a component that can be explained by worker attributes or endowments, and the remaining unexplained component which represents differences in the coefficients. We follow Jann (2008) when estimating the two-fold decomposition of the difference $(D)$ in the mean log wages in the public sector $\left(E\left(Y^{G}\right)\right)$, and the mean $\log$ wages in the private sector $\left(E\left(Y^{P}\right)\right)$ :

$$
D=E\left(Y^{G}\right)-E\left(Y^{P}\right)
$$

The expected log wages by sector $(s)$ are modeled using a linear model, with $X$ being a vector of predictors (gender dummy, educational attainment dummies, formal sector dummy, potential

10 The smaller public-private sector gap in the provision of benefits in Albania to some extent reflects a higher level of private sector formalization of the Albania economy. The ILO estimates that 61 percent of the Albanian economy and 70.4 percent of the Sri Lankan economy in 2013 were informal (ILO 2018). 
labor market experience and its square term, occupational group dummies, cohort dummies, year dummies, and region dummies) and a constant, while $\varepsilon$ is the error term, assumed to have a mean of zero.

$$
Y^{s}=X^{s \prime} \beta^{s}+\varepsilon^{s}, \quad E\left(\varepsilon^{s}\right)=0, \quad s=\{G, P\}
$$

$D$ can then be expressed as the difference in the linear prediction at the group-specific means of the regressors:

$$
D=E\left(Y^{G}\right)-E\left(Y^{P}\right)=E\left(X^{G}\right)^{\prime} \beta^{G}-E\left(X^{P}\right)^{\prime} \beta^{P}
$$

And can be furthermore decomposed as follows:

$$
D=\underbrace{\left[E\left(X^{G}\right)-E\left(X^{P}\right)\right]^{\prime} \beta^{*}}_{\text {explained }}+\underbrace{\left[E\left(X^{G}\right)^{\prime}\left(\beta^{G}-\beta^{*}\right)+E\left(X^{P}\right)^{\prime}\left(\beta^{*}-\beta^{P}\right)\right]}_{\text {unexplained }}
$$

Figure 6. Oaxaca-Blinder decomposition of the public sector pay premium in Albania and Sri Lanka

a. Albania

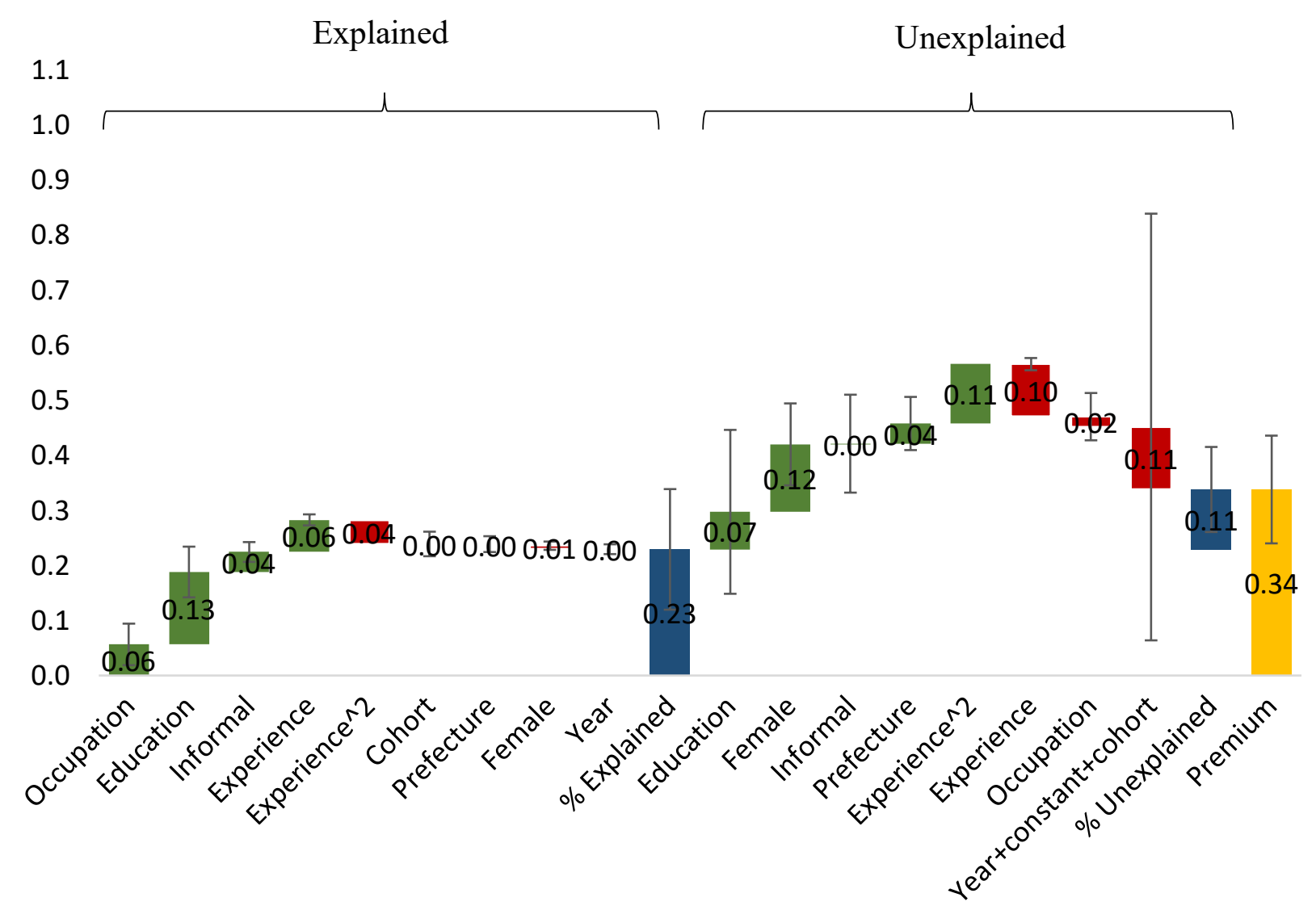


b. Sri Lanka

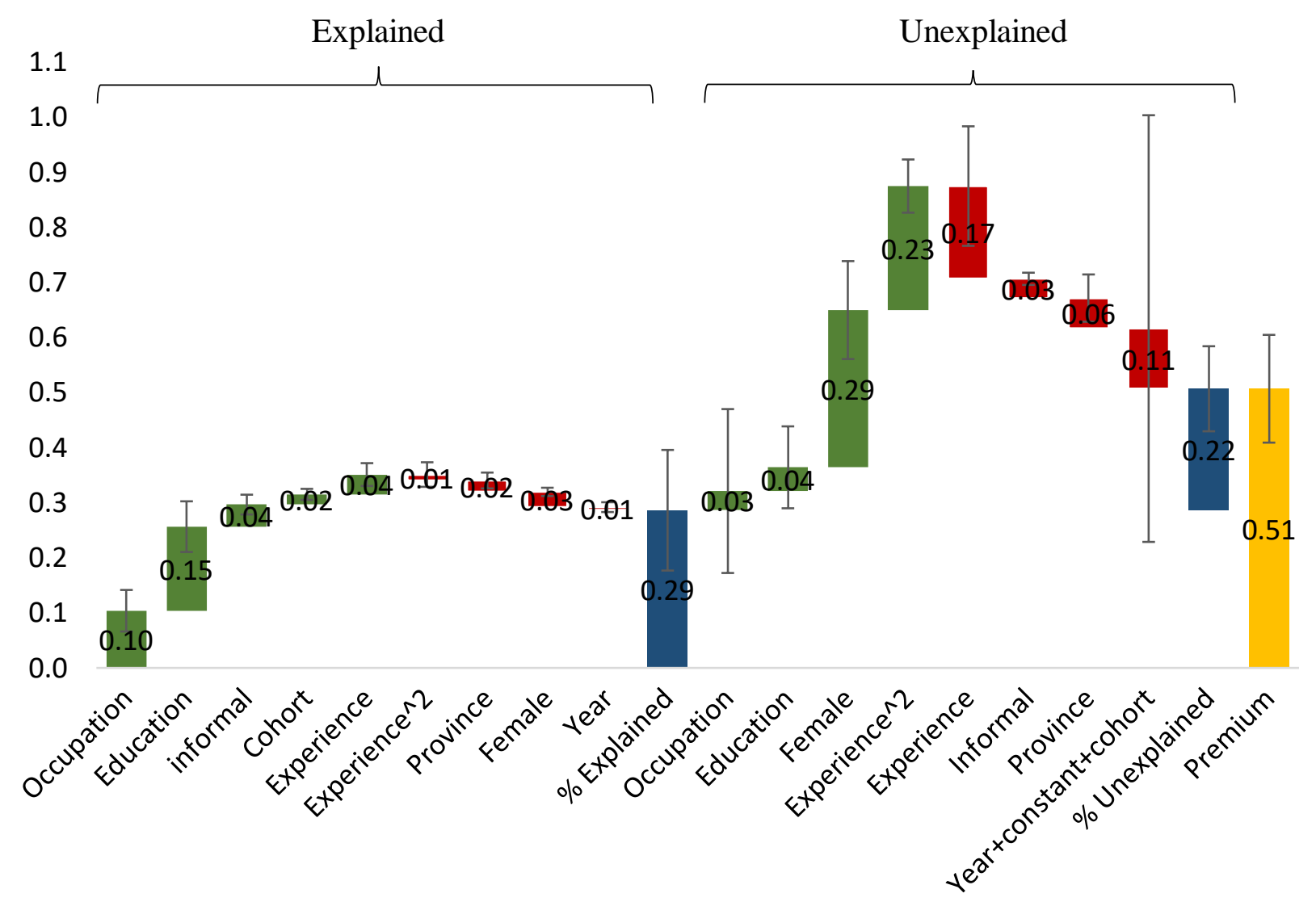

Color legend

Total premium

Breakdown of total premium into explained and unexplained components

Factors with positive contribution to the premium

Factors with negative contribution to the premium

The results are summarized in Figure 6. A breakdown of the explained variance suggests that the most important factors of the pay differences between the public and the private sector are education, followed by occupation, followed by work experience and the fact that part of the private sector is informal. In all of these, the public sector looks more favorable: public sector employees have higher levels of education, work in occupations with higher pay status, have longer work experiences, and are not part of the informal economy. At the same time, the gender structure and the regional distribution of the public sector reduce its average pay: disproportional share of public sector workers are women and this sector tends to be disproportionally present in low-income areas. The impact of the last two factors is marginal, and in the case of Albania, insignificant. These variables combined explain 67.8 percent (22.9 percentage points) of the total pay gap between the public and the private sector in Albania. They explain 56.5 percent (28.6 pp) of the total gap in Sri Lanka. 
If we were to align the educational structure of the two sectors, the pay gap between the two sectors would decline by $13 \mathrm{pp}$ (15 pp) in Albania (Sri Lanka). If we were to align the occupational structure, the gap would decline by 6 pp (10 pp) in Albania (Sri Lanka). If we eliminated informality in the private sector, the pay gap in both countries would decline by 4 pp. Nevertheless, a significant share of the premium remains unexplained by the differences in the sectoral endowments: a third of it in Albania (11 pp gap) and 43.4 percent of it in Sri Lanka (22 pp gap). In particular, $12.2 \mathrm{pp}$ of the unexplained premium in Albania, and $28.6 \mathrm{pp}$ of it in Sri Lanka can be attributed to the fact that the public sector pays women more than the private sector. Another $6.8 \mathrm{pp}$ of the unexplained premium in Albania can be attributed to the public sector paying more, on average, for a year of education.

\subsection{Explaining the public sector pay compression}

The OB decomposition helped us disentangle the differential contributions of the structure of jobs and, to some extent, the contributions of different returns to worker characteristics in explaining the public sector premium. Here, we'd like to delve deeper into the latter issue, in particular because it may be relevant for understanding the sources of pay compression in the public sector. More specifically, the public sector may be equalizing the pay between groups by paying otherwise similar women significantly more than the private sector, and/or by paying otherwise similar workers with less than tertiary education significantly more. Moreover, the observed compression may be a result of the lack of appreciation for individual differences in productivity within narrowly defined groups of peers in the public sector. In the private sector, we expect that salaries are set through employee-employer negotiations in addition to qualifications, and wage increases correlate with individual changes in productivity. In the public sector, wage increases are often decided centrally on behalf of whole groups of employees (for example, teachers or health workers), leaving less space for adjustments to individual-specific productivities.

We are therefore looking for a specification that would help us estimate the extent to which the sector-specific variance can be explained by observable characteristics such as education, occupation and experience, and to what extent by individual-specific unobservable characteristics. We estimate sector-specific Mincerian regressions:

$$
\ln \left(w_{i t}^{S}\right)=\alpha^{s}+\boldsymbol{X}_{\boldsymbol{i t}}^{\boldsymbol{s}} \boldsymbol{\beta}^{\boldsymbol{s}}+\boldsymbol{T}_{\boldsymbol{t}}+\boldsymbol{R}_{\boldsymbol{r}}+\varepsilon_{i t}^{S}, \quad s=\{G, P\}
$$

Where the $\log$ of wages for individual $i$ at time $t$ is modeled as a function of a set of personspecific characteristics $X_{i t}$ (gender dummy, educational attainment dummies, potential labor market experience and its square term, occupational group dummies, and cohort dummies), including controls for year and region fixed effects. We estimate two versions of these equations, one with and one without occupational dummies.11 In addition, using the Albanian data only, we

11 Angrist and Pischke (2009) have argued that if the level of education causally affects our choice of occupation, including controls for occupation constitutes a "bad control" problem, precluding a meaningful interpretation of the coefficients of education (p. 64). 
estimate the above equation, but now including another term $\left(u_{i}\right)$, corresponding to individual fixed effects.

Tables 1 and 2 summarize the findings. Perhaps one of the most significant findings is that, in both countries, a larger share of the variance in public sector wages, as compared to the private sector wages, can be explained by observable characteristics such as gender, education, experience and occupation. Analogously, individual characteristics explain a larger share of the variance in the private sector and a smaller share in the public sector.

Table 1. Differences in the coefficients of Mincerian equations in the public and the private sector Albania

\begin{tabular}{|c|c|c|c|c|c|c|}
\hline & (1) & (2) & \multirow[t]{2}{*}{ (3) } & (4) & (5) & \multirow[t]{2}{*}{ (6) } \\
\hline & Privat & sector & & Public & sector & \\
\hline Female & $\begin{array}{c}-0.205^{* * *} \\
(0.0330)\end{array}$ & $\begin{array}{c}-0.154 * * * \\
(0.0379)\end{array}$ & & $\begin{array}{c}-0.0907 * * * \\
(0.0103)\end{array}$ & $\begin{array}{c}-0.0631 * * * \\
(0.00878)\end{array}$ & \\
\hline Upper secondary general & $\begin{array}{c}0.0813^{* * *} \\
(0.0194)\end{array}$ & $\begin{array}{c}0.0851^{* * *} \\
(0.0212)\end{array}$ & & $\begin{array}{c}0.255^{* * *} \\
(0.0244)\end{array}$ & $\begin{array}{c}0.209 * * * \\
(0.0161)\end{array}$ & \\
\hline Upper secondary vocational & $\begin{array}{c}0.119 * * * \\
(0.0237)\end{array}$ & $\begin{array}{c}0.0947^{* * *} \\
(0.0230)\end{array}$ & & $\begin{array}{c}0.303 * * * \\
(0.0219)\end{array}$ & $\begin{array}{c}0.246 * * * \\
(0.0190)\end{array}$ & \\
\hline Tertiary & $\begin{array}{c}0.614^{* * *} \\
(0.0668)\end{array}$ & $\begin{array}{c}0.446 * * * \\
(0.0542)\end{array}$ & & $\begin{array}{c}0.639 * * * \\
(0.0211)\end{array}$ & $\begin{array}{c}0.504^{* * *} \\
(0.0188)\end{array}$ & \\
\hline Potential experience & $\begin{array}{c}0.0202^{* * *} \\
(0.00344)\end{array}$ & $\begin{array}{c}0.0176^{* * *} \\
(0.00309)\end{array}$ & $\begin{array}{c}0.00164 \\
(0.00690)\end{array}$ & $\begin{array}{c}0.0140 * * * \\
(0.00356)\end{array}$ & $\begin{array}{c}0.0113 * * * \\
(0.00324)\end{array}$ & $\begin{array}{l}-0.00458 \\
(0.00540)\end{array}$ \\
\hline Potential experience ${ }^{\wedge} 2$ & $\begin{array}{c}-0.0004 * * * \\
(4.83 e-05)\end{array}$ & $\begin{array}{c}-0.0003 * * * \\
(3.70 \mathrm{e}-05)\end{array}$ & $\begin{array}{c}-0.0001 \\
(0.000127)\end{array}$ & $\begin{array}{c}-0.0002 * * * \\
(6.47 \mathrm{e}-05)\end{array}$ & $\begin{array}{l}-0.0002^{* *} \\
(6.33 e-05)\end{array}$ & $\begin{array}{c}5.78 \mathrm{e}-05 \\
(0.00016)\end{array}$ \\
\hline Cohort dummies & Yes & Yes & & Yes & Yes & \\
\hline Occupation dummies & No & Yes & & No & Yes & \\
\hline Quarter dummies & Yes & Yes & & Yes & Yes & \\
\hline Region dummies & Yes & Yes & & Yes & Yes & \\
\hline Constant & $\begin{array}{c}4.599 * * * \\
(0.150)\end{array}$ & $\begin{array}{c}4.750 * * * \\
(0.225)\end{array}$ & & $\begin{array}{c}4.776^{* * *} \\
(0.187)\end{array}$ & $\begin{array}{c}4.905^{* * *} \\
(0.200)\end{array}$ & \\
\hline Observations & 13,775 & 13,775 & 11,937 & 11,122 & 11,122 & 10,115 \\
\hline R-squared & 0.307 & 0.429 & 0.931 & 0.412 & 0.478 & 0.936 \\
\hline
\end{tabular}

Observables explain up to 47.8 percent of the variance in the public sector wages in Albania (up to 50.7 percent in Sri Lanka). The same observables explain up to 42.9 percent of the variance in private sector wages in Albania (up to 44.5 in Sri Lanka). This is in line with a world in which public sector wages are primarily set based on job qualifications and seniority, and private sector wages are additionally set based on the person's personality traits, and productivity increases. Table 1 (columns 3 and 6) shows the results of the Mincerian regressions that include individual 
fixed effects.12 Individual fixed effects explain up to 50.2 percent of the pay in the private sector and up to 45.8 percent of the pay in the public sector in Albania.

Table 2. Differences in the coefficients of Mincerian equations in the public and the private sector $-\mathrm{Sri}$ Lanka

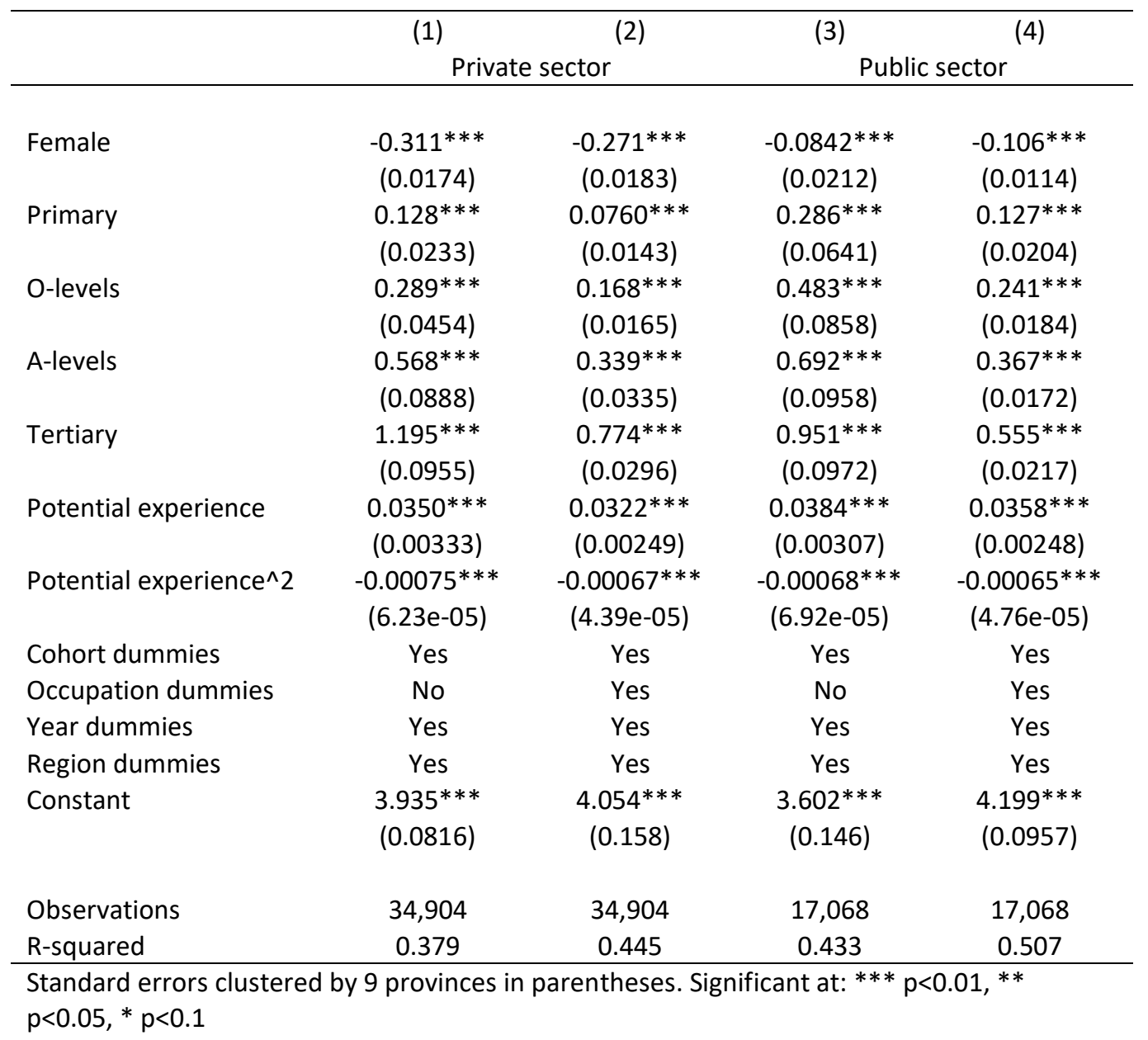

The second notable finding is that, in both countries, the gender pay gap is significantly lower in the public sector. The low gender pay gap however, mainly reflects the sorting of more productive women into the public sector and not less gender discrimination in the public sector.

In Albania (Table 1), the pay penalty for women in the private sector is 15.4 percent after controlling for the occupational differences between men and women (20.5 percent otherwise). In the public sector, it is only 6.3 percent (9.1 percent without occupational controls). Here, the pay penalty for women in the private sector is 27.1 percent, and it is only 10.6 percent in the public sector (31.3 and 8.4 subsequently without occupational controls). Most previous studies also found a higher public sector pay premium among women: Juergens (2002) in Germany,

12 Note that due to collinearity between the person fixed effects and relatively fixed variables such as education and gender, the latter cannot be efficiently estimated and are hence not shown in the table. 
Garcia-Pérez and Jimeno (2005) in Spain, Lucifora and Meurs (2006) in France, Italy and the UK, Kanellopoulos (1997) in Greece and Panizza and Qiang (2005) among Latin American countries. The coefficients estimated here are some combination of the sorting of women into the public sector and the willingness of the public sector to pay them more. It may well be that the public sector is able to attract women that have more similar productivity levels to their male coworkers than is the private sector. Analysis of the estimated person fixed effects from the above equation suggests that this is indeed the case. In both sectors, we estimate that men have higher average unobservable characteristics than women. However, the difference between these distributions is far more pronounced in the private sector (Figure 7). The gender gap in unobservable characteristics $\left(u_{i}\right)$ in the private sector is about a third standard deviation in favor of men, while that in the public sector is less than 6 percent of the standard deviation in favor of men.

Figure 7. Distributions of the estimated time-invariant unobservable characteristics $\left(u_{i}\right)$ by gender and sector

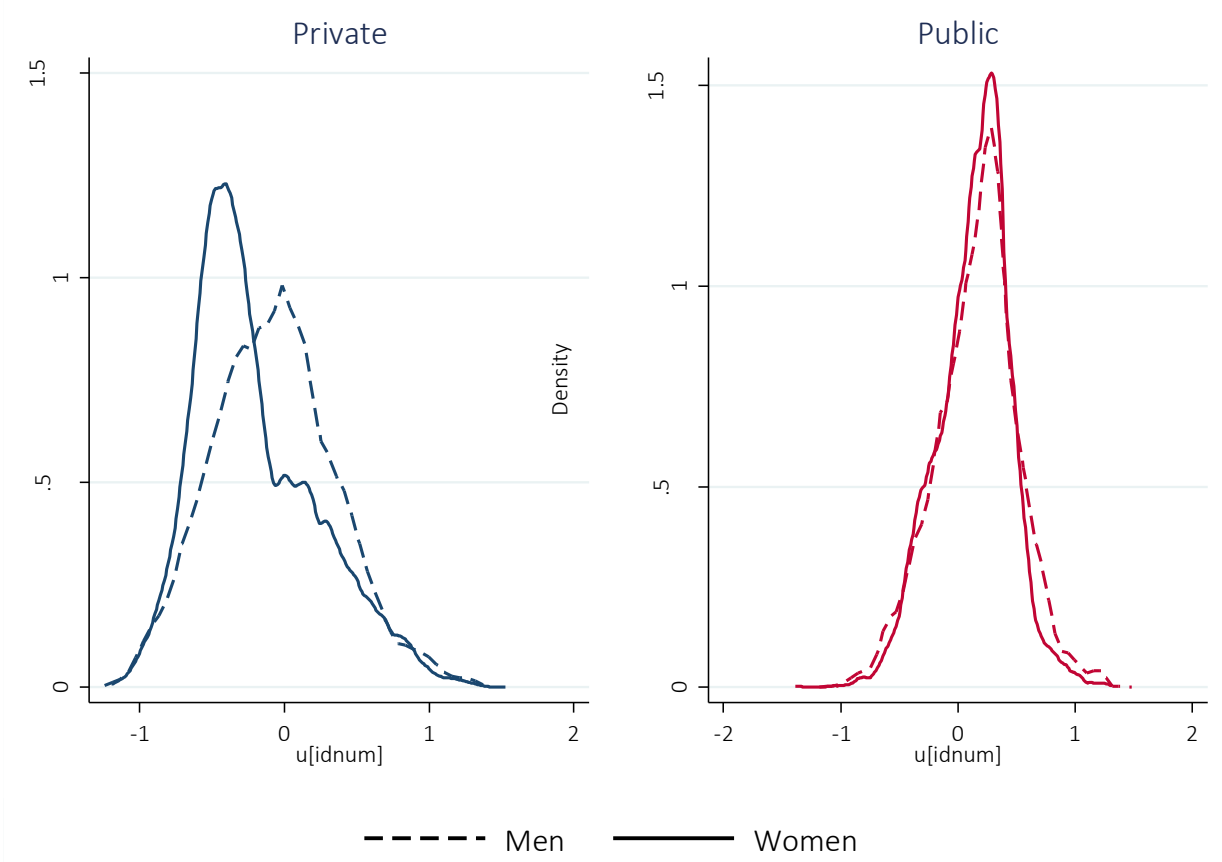

The third noteworthy finding is that, in both countries, the premium to middle-level education is particularly large in the public sector, making the college premium in the public sector relatively small. However, as we will demonstrate in the section six, we find that the middle-skilled public sector employees have significantly better unobservable characteristics than their middle-skilled private sector peers, and that this difference justifies the higher pay they receive in the public sector.

In Albania, the premium to upper secondary general education (compared to primary education only) is 8.1 percent in the private sector, while it is 25.5 percent in the public sector. The premium to upper secondary vocational education is 11.9 percent in the private and 30.3 percent 
in the public sector. The premium to tertiary education is 61.4 percent in the private and 63.9 percent in the public sector, and the difference between the two is not statistically significant. In Sri Lanka, we see a similar pattern (Table 2). The premium to primary education (compared to no education) is 12.8 percent in the private sector and 28.6 percent in the public. The premium to O-levels is 28.9 percent in the private sector and 48.3 percent in the public. The premium to Alevels is 56.8 percent in the private sector and 69.2 in the public, but this difference is not statistically significant. Finally, the premium to tertiary education is 119.5 percent in the private and 95.1 percent in the public, although these differences are again not statistically significant.

Due to the above differences in the sector-specific returns to particular education, we see a lower college premium in the public than in the private sector. In particular, in Albania, the college premium is 35.7 percent in the public sector and 50.3 percent in the private. In Sri Lanka, the college premium is 25.1 percent in the public sector and 59.2 percent in the private.

To conclude, a significant source of pay compression in the public sector is the lower value that the public sector places on individual differences that are not related to formal qualifications such as education, occupation or experience. Moreover, in both countries, the public sector pays more equal wages between men and women, and pays more equal wages among groups with different levels of education. Section six will demonstrate that this kind of wage compression in the public sector results in specific patterns in the employees' self-selection into the public sector.

\subsection{Heterogeneity in the public sector premium}

We now turn to studying the public premium differences along the pay distribution. We find that after controlling for observable employee characteristics, the public sector premium declines with the level of pay in both countries. We also find that within educational groups, the premium becomes insignificant for the best paid medium skilled employees and it turns negative for the best paid highly skilled employees.

Similar to Lucifora and Meurs (2006), we employ quantile regression (Kroenker and Basset, 1982; Rogers 1993) for this purpose. We estimate the public pay premium at various quantiles of the wage distribution, in quantile increments of 0.05 , and plot them accordingly (Figure 8). The upper panel of Figure 8 shows the premium estimates, controlling only for the year of the estimate (unadjusted premium), for Albania (left) and Sri Lanka (right). The lower panel shows the estimates conditional on a set of covariates: gender, level of educational attainment, occupational group (43 groups), potential labor market experience and its squared term, labor market cohort, and year. The dashed lines in each chart show the OLS estimates, and the full lines show the quantile regression estimates and their 95 percent confidence intervals. For ease of reading, all charts use the same scale and include a reference line at zero on the y axis.

In both countries, the unadjusted premium has an inverted $U$ shape, but with some differences. In Albania, it is the employees between the second decile and the median of the wage distribution that enjoy the highest premium. In Sri Lanka, this is the case with the middle-paid employees. In 
both countries, the highest paid employees enjoy the lowest premium. After controlling for observables, this shape changes, and the overall premium declines in magnitude at all deciles of the wage distribution. In Albania, the premium declines almost monotonically: the least paid workers enjoy the largest premium of about 25 percent, while the best paid workers even have a pay penalty of about 5 percent. In Sri Lanka, the premium is high and similar in magnitude (between 28 and 32 percent) for the workers in the first half of the wage distribution, and it declines monotonically afterwards, but never becomes negative.

Figure 8. Quantile regression estimates of the public sector pay premium in Albania and Sri Lanka

a. Albania: unadjusted premium $\quad$ b. Sri Lanka: unadjusted premium
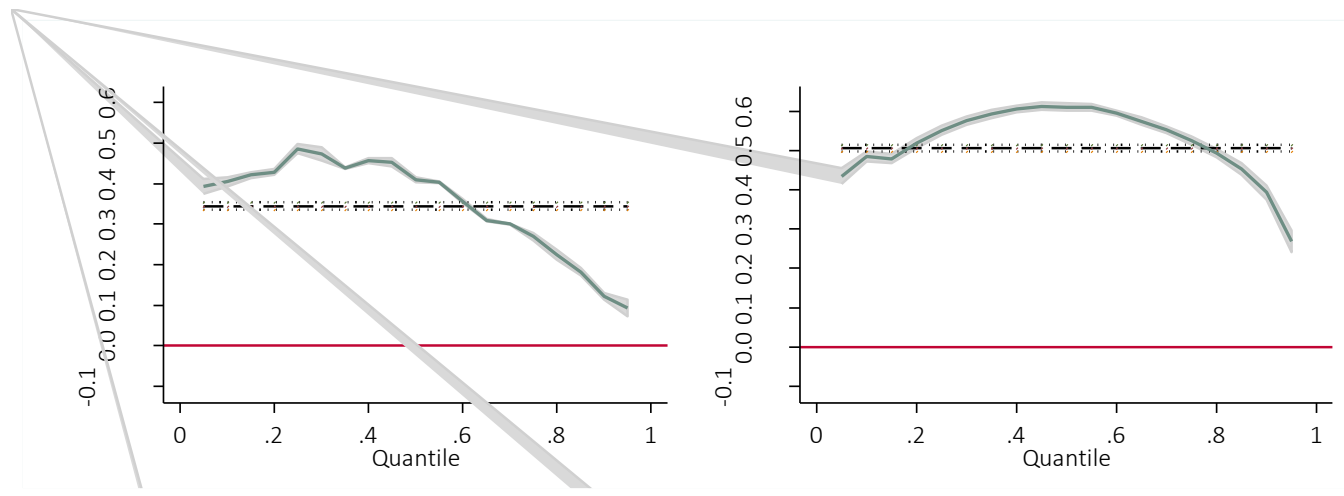

a. Albania: conditional premium

b. Sri Lanka: conditional premium
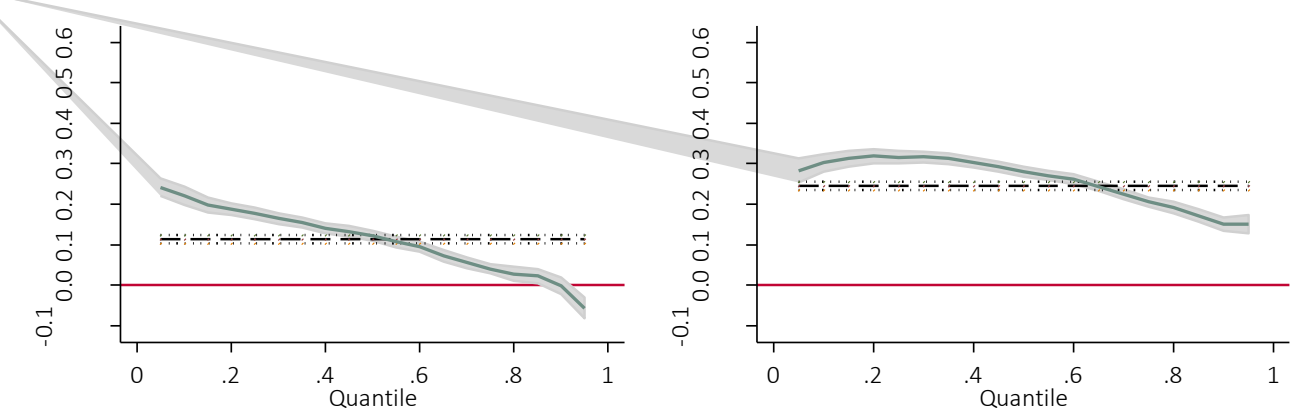

Note: The regressions behind the upper panel estimates only control for the year at which the pay gap is calculated. Robust standard errors are used to estimate the 95 percent confidence intervals for the quantile regression estimates. The lower panel estimates control for gender, level of education (4 categories), occupation (43 groups), cohort (decade of entry), year, potential experience and its square term. Because of discontinuities in Sri Lanka's occupational classification, the latter sample only includes years 2013, 2014 and 2015. 
Figure 9 shows the public premium by quantile within levels of educational attainment.13 For those with primary education in Sri Lanka and those with primary or lower secondary education in Albania, the premium is always positive and coincides with the OLS estimate for this group. For all other education groups, and in both countries, the premium declines with the level of pay. The premium is about zero for the best paid employees with upper secondary education in Albania and for the best paid employees with A-levels in Sri Lanka. In Albania, the premium is negative for tertiary educated workers who earn above the 60 th percentile of the wage distribution in this education category. In Sri Lanka, the premium is negative for all tertiary educated workers that earn above the 25 th percentile of the wage distribution in this group.

Figure 9. Quantile regression estimates of the public sector pay premium by level of education

a. Albania
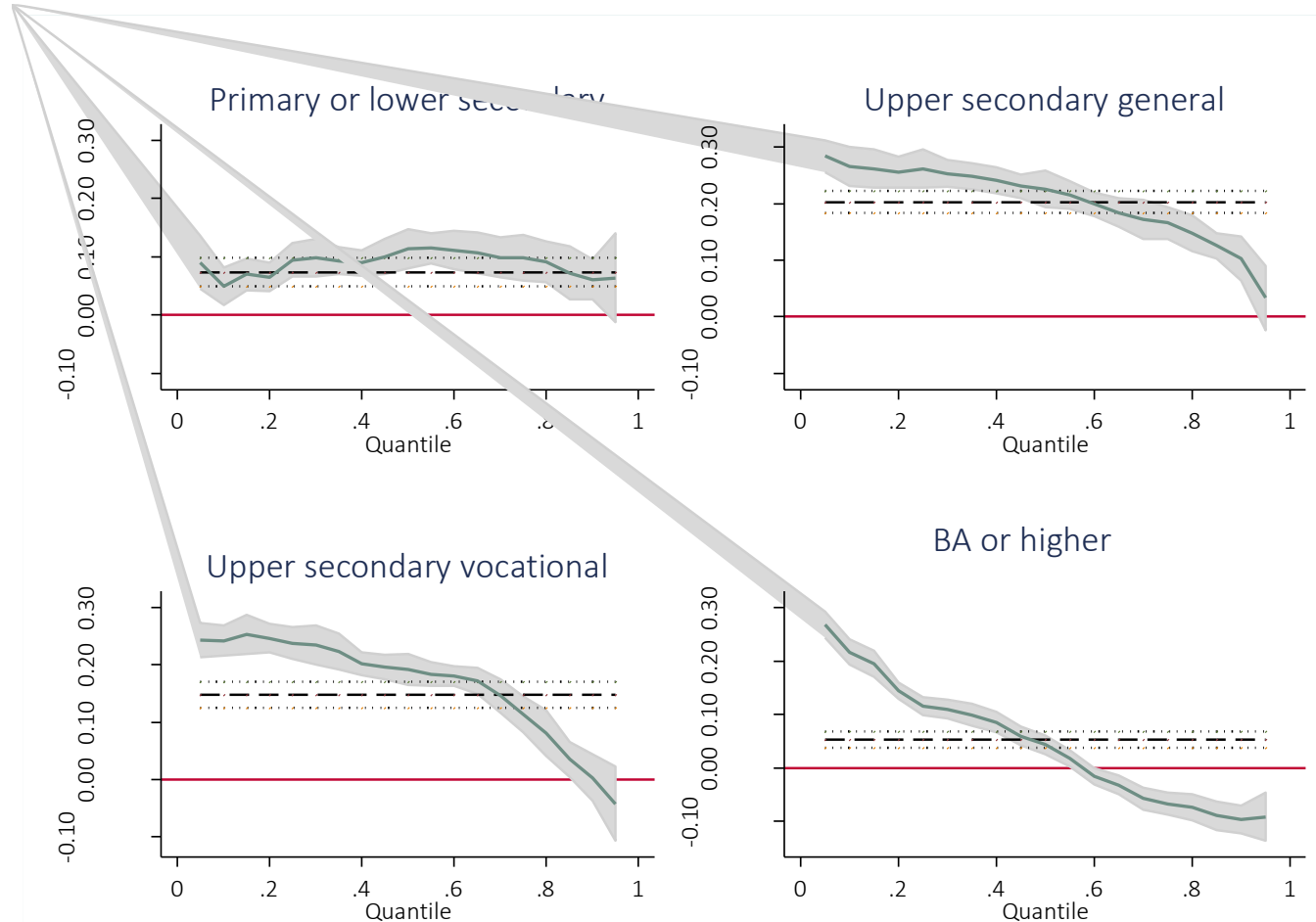

13 It is important not to conflate the level of pay with the level of education in the two countries. While pay is highly correlated with the years of educational attainment $(\rho=0.52)$ in both countries, this is far from a perfect correlation. What is more, the correlation is lower for the private sector: $\rho=0.37$ in Albania and $\rho=0.41$ in Sri Lanka. For men in the private sector, it is as low as $\rho=0.27$ in Albania and $\rho=0.42$ in Sri Lanka. We observe the highest correlations among women in the public sector: $\rho=0.62$ in Albania and $\rho=0.57$ in Sri Lanka. 


\section{b. Sri Lanka}

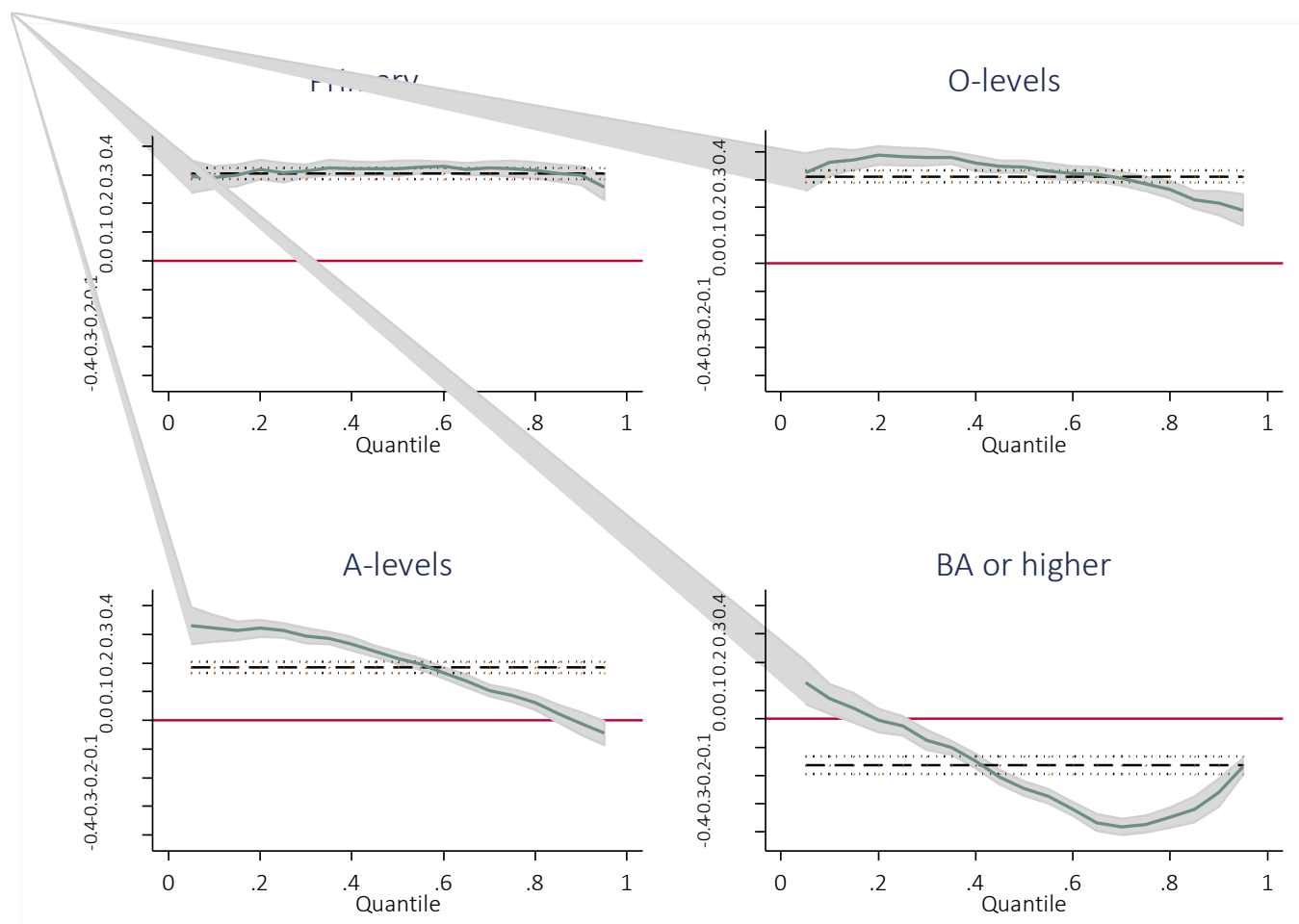

In summary, while on average positive, the public sector premium varies greatly with the level of pay, even for employees with similar levels of educational attainment. In both countries, the premium becomes negative for a sizable share of highly paid tertiary educated employees. It also approaches zero for the best paid employees with upper secondary education in Albania and for the best paid employees with A-levels in Sri Lanka. Our results are similar to the findings by Hospido and Moral-Benito (2016), who find that in Spain, the public premium turns negative for the best paid highly skilled male employees and approaches zero for the medium skilled male employees. These patterns now clearly show the possible disadvantage of a compressed wage structure - a disincentive for the best and the brightest of all to join and stay in the public sector. The next section studies whether such self-selection took place in Albania.

\section{Self-selection into the public sector}

It is by now evident that in both countries, at the bottom and at the middle of the skill-wage distribution, individuals have clear incentives to opt for the public sector. Here, the public sector pays equal or higher hourly wages than the private sector and it is significantly more likely to offer pensions, permanent contracts, and fringe benefits such as paid leave.14 At the top of the

14 The value attached to such benefits can by far exceed the pay premium. An experiment among workers in Bangladesh, for instance, revealed that the average worker without a written contract would be willing to forgo a 27 percent increase in monthly income in order to obtain a one-year written contract (Mahmud et al. 2019). 
skill-pay distribution, the incentives shift in favor of the private sector: here the private sector pays better and also provides pensions, permanent contracts and fringe benefits to most of its workers.

In order to test whether the differences in the pay and benefits schemes between the two sectors affect the kinds of individuals they are able to attract, we study the within-person variance in wages stemming from individual transitions between the public and the private sector. This analysis is only possible for Albania, where we have individual-level panel data. In the period 2012-2016, we observe 580 transitions between the two sectors. In terms of direction, 295 transitions are from the public to the private sector, and 285 are in the opposite direction. This means that on an annual basis, 12.8 percent of public sector employees moved to the private sector, and 10.8 percent of private sector employees moved to the public sector.

Having in mind the group heterogeneity discussed above, but also the limited number of sectoral transitions, we focus on estimating the mean premium for four education groups. The group of the tertiary educated, which constitutes 35 percent of all public sector workers, is further divided into those who earn median or below median wages for this group, and those who earn above median wages. This will allow us to capture the fact that the premium for this group reverses from positive to negative as the level of pay increases. We estimate:

$$
\ln \left(w_{i t}^{E}\right)=\alpha^{E}+\beta S_{i t}^{E}+\boldsymbol{X}_{i t}^{E^{\prime}} \boldsymbol{\beta}^{E}+\boldsymbol{T}_{\boldsymbol{t}}+\boldsymbol{R}_{\boldsymbol{r}}+u_{i}^{E}+\varepsilon_{i t}^{E}, S \in\{G, P\},
$$

$E=\{$ primary,

upper secondary general,

upper secondary vocational,

tertiary low pay,

tertiary high pay\}

Where $u_{i}$ indicates the individual time invariant characteristics such as personality traits or ability.

In accordance with the discussion above, after including individual fixed effects, we expect that a positive public premium will be reduced or even become negative if workers are positively sorted in the public sector. Similarly, after controlling for individual FE, a negative public premium would be corrected towards zero, and may even become positive, if public sector workers are negatively sorted.

Our findings are summarized in Figure 10. The Figure compares the OLS and FE results for five groups of workers: four different educational groups, with the last one split in two by their level of pay (below and above median pay). While the OLS estimates are in line with the ones presented in subsection 5.3., the inclusion of $u_{i}$ turns our estimates of the public premium almost upside down. For the full sample, the estimate goes down from 12.7 percent in the OLS 
specification to 8 percent in the FE specification. 15 The premium is now close to zero for those with a general secondary education or lower; it is close to 3 percent (but not statistically different than zero) for those with a vocational secondary education. For the tertiary educated that earn the median or less within this group, the premium declines from 17.1 percent to an insignificant 4.9 percent. For the best paid tertiary educated workers, the negative 5.3 percent premium is now reversed to a positive premium of 3.7 percent. These findings suggest that the majority of public sector workers are positively selected compared to their peers in the same education category. The best paid highly skilled workers, on the other hand, are negatively selected.

Figure 10. Comparison of the public premium OLS and FE estimates by level of education, Albania

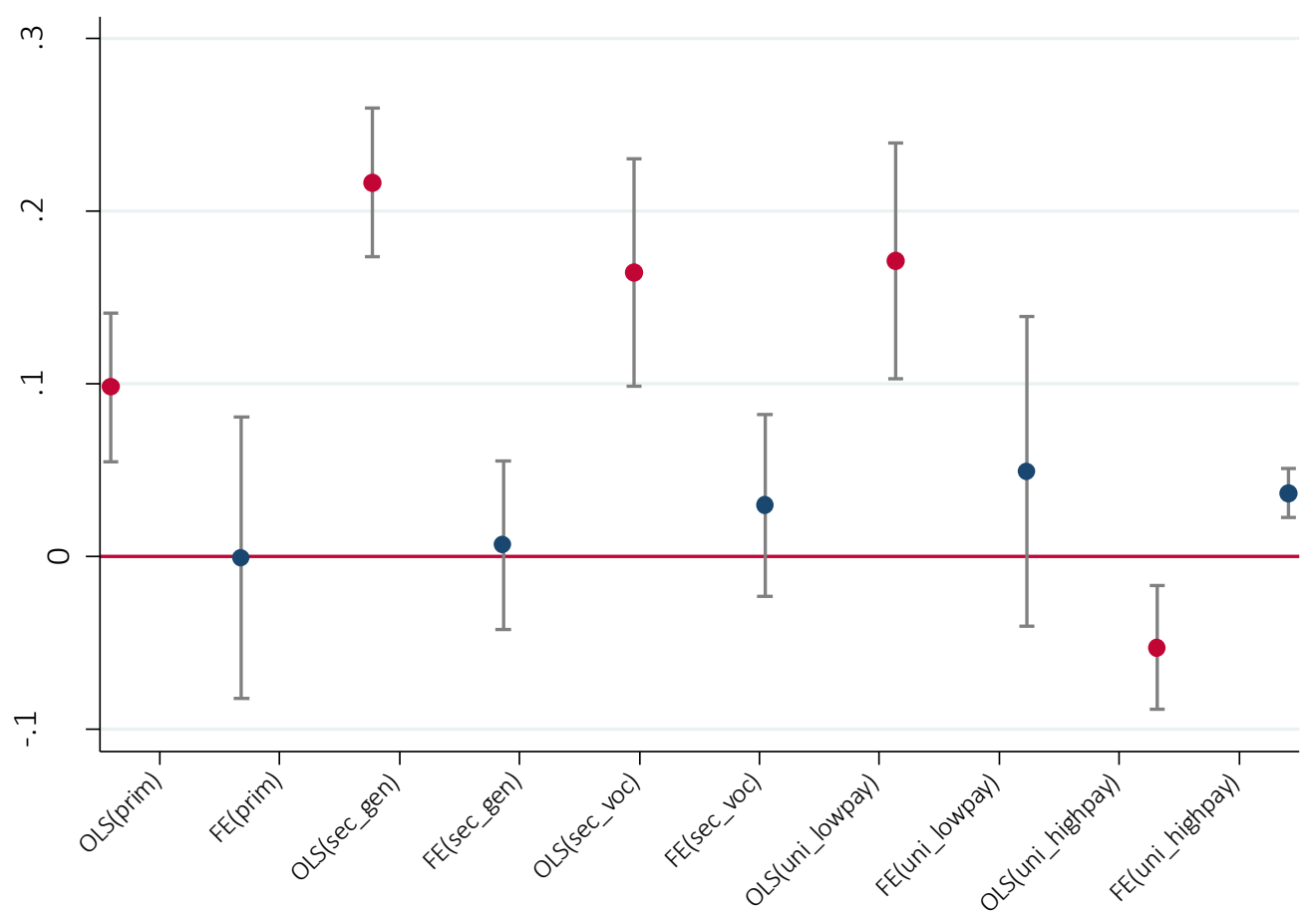

Note: Figure 10 plots the coefficients of the public sector dummy estimated in ten separate regressions (five OLS and five FE regressions), and their corresponding 95 percent confidence intervals, which are clustered by prefecture. The red markers correspond with the OLS estimates and the blue markers, with the FE estimates. The OLS results include controls for gender, educational attainment, 43 occupation dummies, 12 prefecture dummies, 6 cohort dummies, 5 year dummies, potential labor market experience and its square term. The FE estimates include controls for year, potential labor market experience and its square term.

15 Figure B1 in the appendix plots the estimated individual fixed effects for the public and the private sector (full sample and by level of education). The mean of the public sector individual effects distribution is to the right of the private sector mean for all samples but the tertiary educated, suggesting positive sorting into the public sector. 


\section{Conclusions and discussion}

This paper studies the factors behind the public sector premium in Albania and Sri Lanka, the group heterogeneity in the premium, the sources of public sector wage compression, and the impact of this compression on the way individuals self-select between the public and the private sector.

Similar to other countries, the public sectors in Albania and Sri Lanka pay higher wages than the private sector, for all but the most skilled employees. Moreover, the government sector offers pensions, permanent contracts and fringe benefits to majority of its employees, as opposed to the private sector where these are mainly reserved for the most valued employees. The value of these additional benefits may in fact by far outweigh that of the pay premium.

We show that, in comparison with the private sector, the pay schemes of the public sector compress the pay distribution by being less sensitive to differences in individual characteristics beyond one's qualifications. This probably reflects some of the basic differences in the wagesetting between the two sectors. The public sector pay-schemes primarily set rewards based on one's qualifications, while the private sector pay-schemes additionally allow for wages to be negotiated based on the one's personality traits and negotiation skills. Government wage increases often follow tenure-based fixed schedules, while those of the private sector are more aligned with changes in employee productivity and negotiations-related behavior.

Two other potential channels of the observed wage compression in the public sector were also analyzed: the remarkably high returns to secondary education and the low gender pay gap. While the wage setting system in the public sector may have initially caused compression through arbitrarily equalizing the pay between educational groups and between the genders, in both of these aspects we find that the self-selection of workers is such that better able secondary educated employees and better able women (as compared to their private sector counterparts) justify the higher group-specific pay. In other words, even if the public sector initially created differential rewards to having secondary education and to being a woman, the subsequent positive sorting of employees into the public sector seems to have closed the productivity-pay gap. While we are not able to tell in which direction the causality goes, and it is possible that it goes in both directions, we conjecture that the more likely scenario is one where the rigid pay schedules incentivize individuals with certain abilities to sort into the public sector. It is more likely that the public sector sets the pay for a whole group (teachers, healthcare workers etc.), and subsequently, the more productive employees from these groups compete for the public sector jobs, than that more productive employees were there first and negotiated their way to what seem to be above-market salaries.

The public sector compression in pay and benefits has some, perhaps unintended, negative consequences when it comes to its attractiveness for scarce highly-skilled talent that is also valued in the private sector. The public sector premium for the top jobs is negative and the private sector is almost as generous as the public when it comes to the pensions and fringe 
benefits in top jobs. With this, the public sector simply sets strong incentives for positive selfselection among all, but its most valued employees. In Albania, where the availability of individual-level panel data enables us to follow employees as they transition between the private and the public sector, we find that, unlike everyone else, the best educated and the best paid government employees are indeed negatively selected.

The policy significance of the above findings became evident in the year immediately following the period covered in this study. When the Albanian government adjusted public sector salaries in 2017 after a four-year freeze, it decided to distribute the bulk of the raise to the middle-paid employees. In hindsight, a more economically sound decision would have been to increase the pay for the top employees in the skill-pay distribution. In that way, the public sector would have come closer to paying market wages for its best workers, which in turn would help attract and retain talent and experience in the sector. This suggests that near-future pay increases should be reserved for the top civil servants. In order to avoid the creation of distortive incentives, governments more generally may benefit from closely monitoring and comparing the pay and benefits offered to various groups of workers in the private sector.

A few limitations to this study can be addressed in future research. Our estimation of the sorting patterns in the Albanian labor market uses the mobility of workers between the two sectors as identifying variation. However, people clearly do not move between jobs randomly. Ideally, the identifying variation should come from moves of individuals that experienced job separations unrelated to their productivity and job match. We do not have such shocks in our data and to the best of our knowledge, such data does not exist in the countries studied here. Better data should also allow us to observe rates of job quits for different groups, in order to test if the heterogeneity in the public pay premium indeed translates into higher quit rates among best workers for instance.

Furthermore, scholars have shown that in some countries the public sector earnings are often complemented by bribes. While in those countries the public sector premium has actually been found to be negative, the question of whether bribes complement the pay of at least some civil servants is an important one. In Albania, for instance, a recent investigation of the appeals court judges showed that nearly 80 percent of them could not justify their wealth in one or more years during their judicial careers (Likmeta, 2016), suggesting that at least among some professions where the public sector pays less than the private, bribes are widespread.

Finally, people in developing economies today do not only choose between working in the public and working the private sector, but also between working in their home countries and working abroad. This is particularly the case in countries like Albania, where the individual prospect of working in an EU country is quite viable and where estimated 60 percent of all adults report a desire to migrate permanently (Esipova, Pugliese and Ray, 2018). Scarce talent is probably fleeing both the public and the private sector in an environment where your immediate EU neighbors offer incomes that are multiples of what any job can offer at home. The field needs an 
approach that would incorporate the option to migrate into the decision-making process of workers.

\section{Acknowledgements}

We would like to thank Therese Danley, Semiray Kasoolu, Tim O'Brien, Frank Neffke, and Daniel Stock from helpful comments. Financial support for this research comes from the Open Society Foundations, [grant number OR2013-10995 Economic Growth in Albania, and grant number OR2016-27991 Sustainable and Inclusive Economic Growth and Governance in Sri Lanka] granted to the Center for International Development at Harvard University. 


\section{References}

Angrist, J. D., \& Pischke, J. S. (2009). Mostly harmless econometrics: An empiricist's companion. Princeton university press.

Blinder, A. S. (1973). Wage discrimination: reduced form and structural estimates. Journal of Human resources, 436-455.

Borjas, G. J. (1980). Wage determination in the federal government: The role of constituents and bureaucrats. Journal of Political Economy, 88(6), 1110-1147.

Borjas, G. J. (2002). The wage structure and the sorting of workers into the public sector (No. w9313). National Bureau of Economic Research.

Borjas, G.J., 1984. Electoral cycles and the earnings of federal bureaucrats. Economic Inquiry, 22(4), pp.447-459.

Courant, P. N., Gramlich, E. M., \& Rubinfeld, D. L. (1979). Public employee market power and the level of government spending. The American Economic Review, 69(5), 806-817.

Depalo, D., Giordano, R., \& Papapetrou, E. (2015). Public-private wage differentials in euroarea countries: evidence from quantile decomposition analysis. Empirical Economics, 49(3), 985-1015.

Department of Census and Statistics (2017, September). Sri Lanka Labour Force Survey Annual Report - 2016 Retrieved from http://www.statistics.gov.lk/samplesurvey/LFS_Annual\%20Report_2016.pdf

Disney, R. (2007). Public-private sector wage differentials around the world: methods and Esipova, N., Pugliese A., \& Ray, J. (2018). More Than 750 Million Worldwide Would Migrate If They Could. Gallup News. Retrieved from: https://news.gallup.com/poll/245255/750-millionworldwide-migrate.aspx

Gindling, T. H., Hasnain, Z., Newhouse, D. L., \& Shi, R. (2019). Are Public Sector Workers in Developing Countries Overpaid? Evidence from a New Global Data Set. The World Bank.

Gorodnichenko, Y., \& Peter, K. S. (2007). Public sector pay and corruption: Measuring bribery from micro data. Journal of Public economics, 91(5-6), 963-991.

Gregory, R. G., \& Borland, J. (1999). Recent developments in public sector labor

markets. Handbook of labor economics, 3, 3573-3630.

The Guardian, (2013). From the archive, 22 July 1960: Sri Lanka Elects World's First Woman Prime Minister. Retrieved from:

https://www.theguardian.com/theguardian/2013/jul/22/bandaranaike-first-woman-prime-minister 
Hausmann, R. (2018, November 14). How Not to Fight Income Inequality. Project Syndicate. Retrieved from https://www.project-syndicate.org/commentary/mexico-mistaken-plan-to-lowerpublic-salaries-by-ricardo-hausmann-2018-11?barrier=accesspaylog

Holmlund, B. (1993). Wage setting in private and public sectors in a model with endogenous government behavior. European Journal of Political Economy, 9(2), 149-162.

Hospido, L., \& Moral-Benito, E. (2016). The public sector wage premium in Spain: evidence from longitudinal administrative data. Labour Economics, 42, 101-122.

ILO (2018). Women and men in the informal economy: a statistical picture (third edition). International Labour Office - Geneva

INSTAT. (2017). Labour Force Survey Q3-2016. Retrieved from http://www.instat.gov.al/en/themes/labour-market-and-education/employment-andunemployment-from-lfs/publication/2016/labour-force-survey-q3-2016/

INSTAT. (2019a, September). Wage Statistics. Retrieved from http://www.instat.gov.al/media/6225/wage-statistics-q2-2019.pdf

INSTAT. (2019b). Average gross monthly wage per employee and approved minimum wage by type and year. Retrieved from http://databaza.instat.gov.al/pxweb/en/DST/START_PKP_PTM/PTM011/?rxid=6b48a5df71c6-49be-b1e7-c0dbfa181338

Jann, B., 2008. A Stata implementation of the Blinder-Oaxaca decomposition. Stata journal, 8(4), pp.453-479.

Jürges, H. (2002). The distribution of the German public-private wage gap. Labour, 16(2), 347381.

Kanellopoulos, C. N. (1997). Public-private wage differentials in Greece. Applied Economics, 29(8), 1023-1032.

Katz, L., \& Autor, D. (1999). Changes in the Wage Structure and Earnings Inequality. Ashenfelter, O. and D. Card (eds), Handbook of Labor Economics., 3A: 1463-1555.

Koenker, R., \& Bassett Jr, G. (1978). Regression quantiles. Econometrica: journal of the Econometric Society, 33-50.

Likmeta, B. (2016, June). The Integrity Gap: Albania's Appeals Court Judges Asset Disclosures Raise Red Flags. Retrieved from https://balkaninsight.com/2016/06/17/the-integrity-gap-albanias-appeals-court-judges-asset-disclosures-raise-red-flags-06-16-2016/

Lucifora, C., \& Meurs, D. (2006). The public sector pay gap in France, Great Britain and Italy. Review of Income and wealth, 52(1), 43-59. 
Mahmud, M., Gutierrez, I. A., Kumar, K., \& Nataraj, S. (2019). What aspects of formality do Workers value? Evidence from a choice experiment in Bangladesh.

Mizala, A., Romaguera, P., \& Gallegos, S. (2011). Public-private wage gap in Latin America (1992-2007): A matching approach. Labour Economics, 18, S115-S131.

Mueller, R. E. (1998). Public-private sector wage differentials in Canada: evidence from quantile regressions. Economics Letters, 60(2), 229-235.

Oaxaca, R. (1973). Male-female wage differentials in urban labor markets. International economic review, 693-709.

Panizza, U., \& Qiang, C. Z. W. (2005). Public-private wage differential and gender gap in Latin America: Spoiled bureaucrats and exploited women?. The Journal of Socio-Economics, 34(6), 810-833.

Panizza, U., di Tella, R., \& Van Rijckeghem, C. (2001). Public sector wages and bureaucratic quality: Evidence from Latin America [with comments]. Economía, 2(1), 97-151.

Pérez, J. I. G., \& Serrano, J. F. J. (2005). Public sector wage gaps in Spanish regions. Documentos de trabajo del Banco de España, (26), 9-51.

Reder, M. (1975). The theory of employment and wages in the public sector. Labor in the public and nonprofit sectors, 1,48 .

Whelan and Montes (2018). Mexico's New President Will Take a Pay Cut. That Means Cuts for Others. Retrieved from WSJ: https://www.wsj.com/articles/mexicos-new-president-will-take-apay-cut-that-means-cuts-for-others- 1533029402

World Bank, 2019 New Country Classifications by Income Level: 2019-2020. Retrieved from: https://blogs.worldbank.org/opendata/new-country-classifications-income-level-20192020?fbclid=IwAR3gkSoxhIjTSuxJzaLmwI6rMKhLwOY-vT_vIVutL10oW_AQuvcuqw5Dww 


\section{Appendix A: Descriptive statistics}

Table A1. Summary statistics for the final samples

a. Albania

\begin{tabular}{lrrrr} 
& Mean & Std. Dev. & Minimum & Maximum \\
\hline In(wages) & 5.09 & 0.44 & 3.76 & 7.09 \\
Potential experience & 22.28 & 11.99 & 0.00 & 49.00 \\
Public sector & $44.7 \%$ & & & \\
Female & $42.5 \%$ & & & \\
Education & & & \\
$\quad$ Primary and lower secondary & $22.1 \%$ & & \\
$\quad$ Upper secondary general & $26.4 \%$ & & \\
Upper secondary vocational & $16.3 \%$ & & \\
$\quad$ Tertiary & $35.2 \%$ & & \\
Occupations (selected, larger) & & & \\
$\quad$ Professionals & $21.6 \%$ & & \\
$\quad$ Technicians & $12.4 \%$ & & \\
$\quad$ Service and sales & $19.1 \%$ & & \\
Crafts and related & $15.3 \%$ & & \\
Plant and machine operators, & & & \\
assemblers & $13.0 \%$ & & \\
$\quad$ Elementary occupations & $8.5 \%$ & & \\
\hline
\end{tabular}

Number of observations: 24,897 
b. Sri Lanka

\begin{tabular}{lrrrr} 
& \multicolumn{2}{c}{ Std. } & & \\
& Mean & Dev. & Minimum & Maximum \\
\hline In(wages) & 4.60 & 0.61 & 2.96 & 6.29 \\
Potential experience & 20.89 & 11.95 & 0.00 & 49.00 \\
Public sector & $32.8 \%$ & & & \\
Female & $35.1 \%$ & & & \\
Education & & & \\
$\quad$ Less than primary & $27.4 \%$ & & \\
Primary & $25.3 \%$ & & \\
O-Levels & $17.7 \%$ & & \\
A-Levels & $21.0 \%$ & & \\
Tertiary & $8.6 \%$ & & \\
Occupations (selected, larger) & & & \\
Professionals & $10.0 \%$ & & \\
Technicians & $11.3 \%$ & & \\
Service and sales & $12.4 \%$ & & \\
Crafts and related & $14.5 \%$ & & \\
Plant and machine operators, assemblers & $9.9 \%$ & & \\
Elementary occupations & $26.2 \%$ & \\
\hline
\end{tabular}

Number of observations: 51,972

Figure A1. Public to private sector log wage ratio, over time, by educational level, and gender

a. Albania
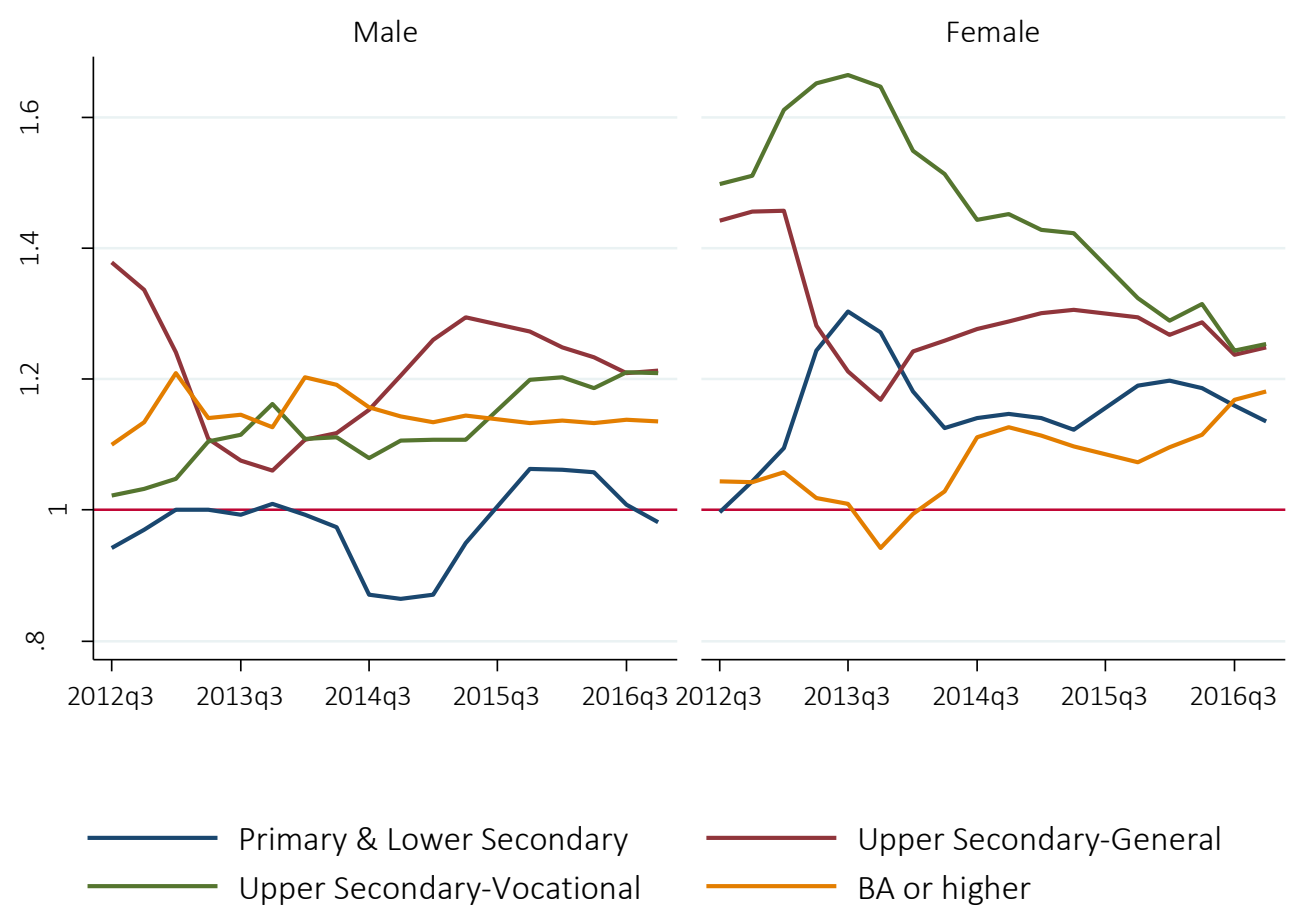
b. Sri Lanka

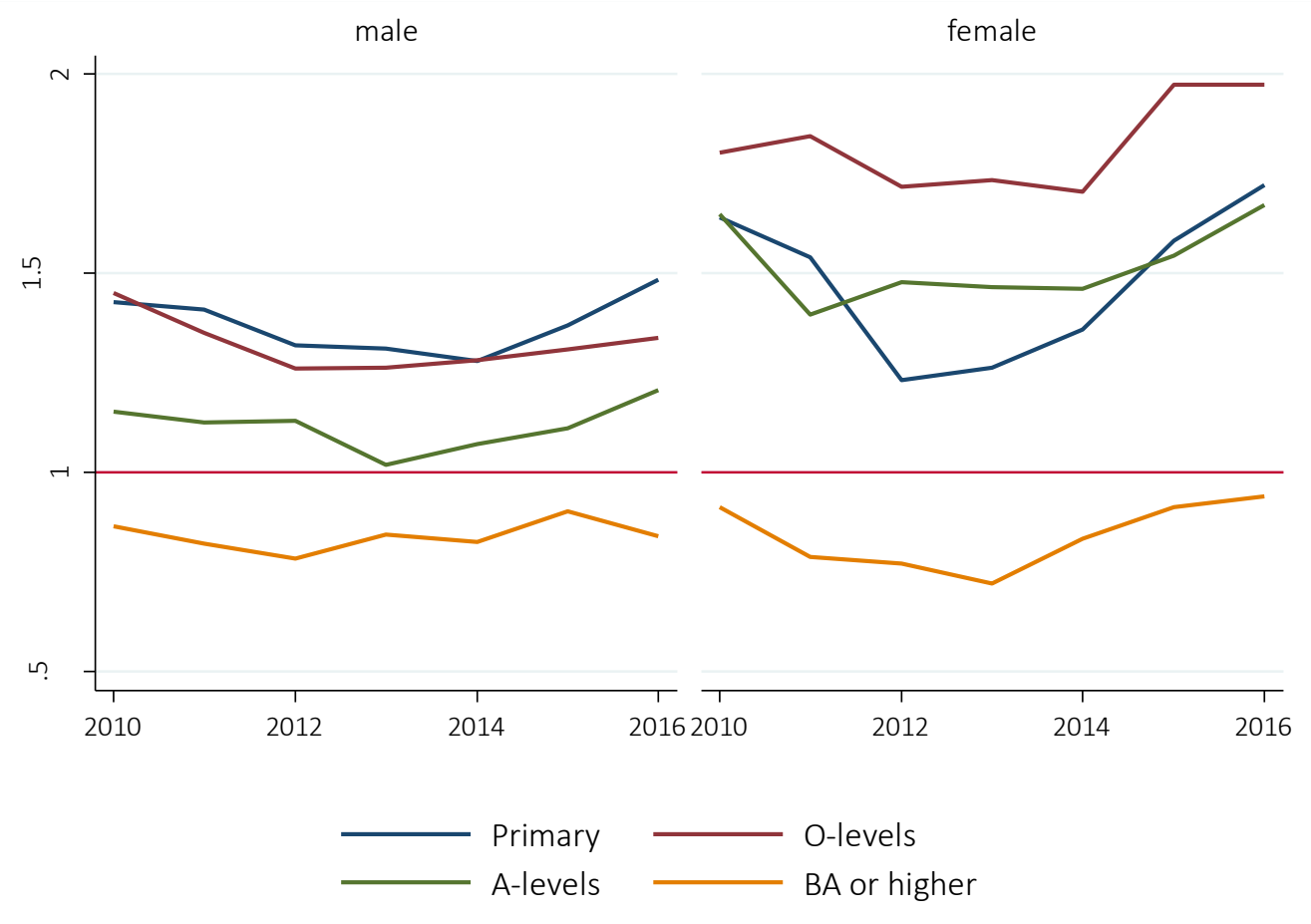


Appendix B: Analysis of the individual fixed effects

Figure B1. Fixed effects by sector and level of education
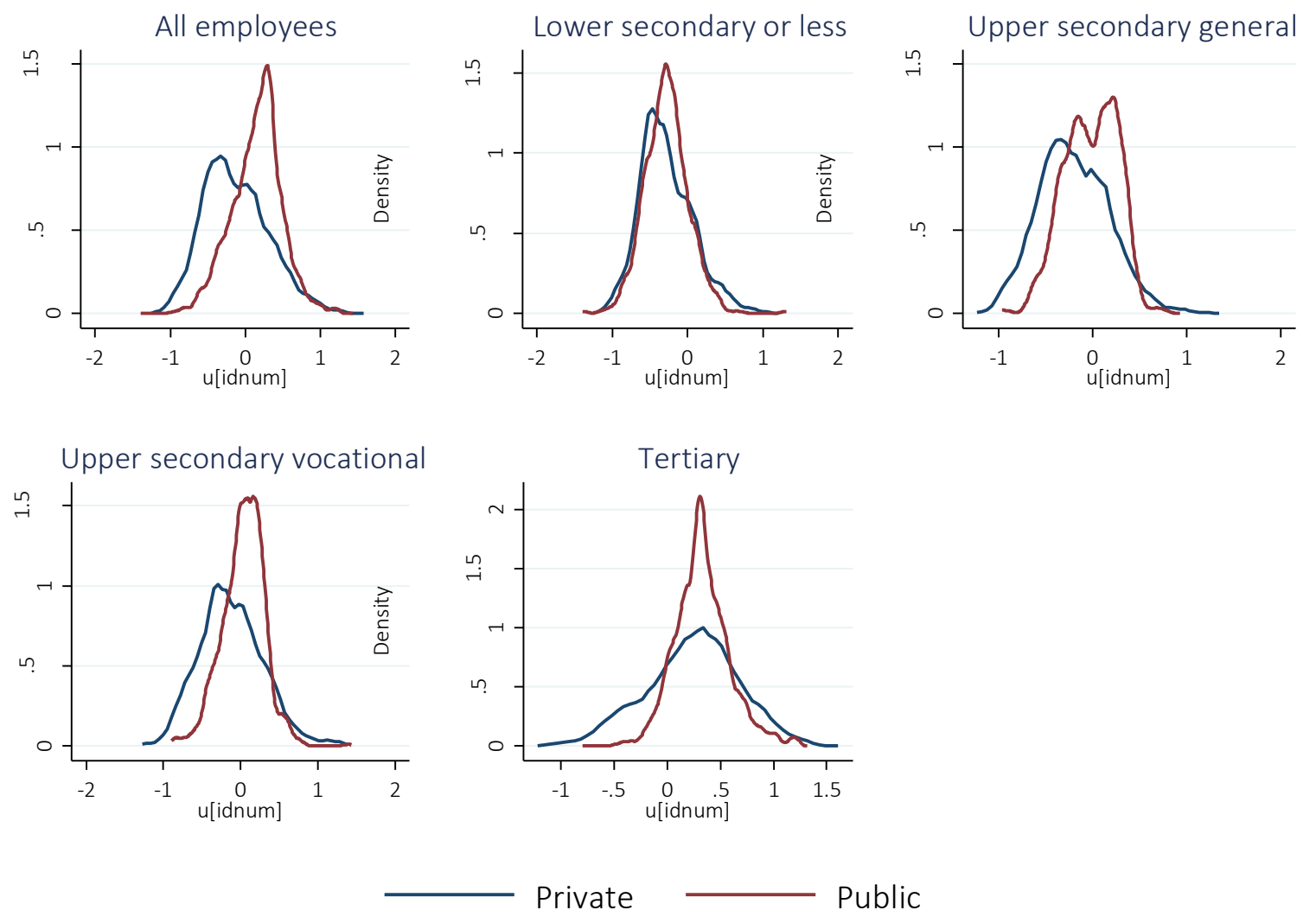